\title{
Dual Roles of Microglia in the Basal Ganglia in Parkinson's Disease
}

\author{
Mohammed E. Choudhury, Yuka Kigami and Junya Tanaka *(D) \\ Department of Molecular and Cellular Physiology, Ehime University Graduate School of Medicine, \\ Shitsukawa, Toon, Ehime 791-0295, Japan; mechoudhury81@gmail.com (M.E.C.); \\ d401027z@mails.cc.ehime-u.ac.jp (Y.K.) \\ * Correspondence: jtanaka@m.ehime-u.ac.jp; Tel.: +81-89-960-5241
}

Citation: Choudhury, M.E.; Kigami, Y.; Tanaka, J. Dual Roles of Microglia in the Basal Ganglia in Parkinson's Disease. Int. J. Mol. Sci. 2021, 22, 3907. https://doi.org/10.3390/ ijms22083907

Academic Editor:

Antonella Scorziello

Received: 1 March 2021

Accepted: 7 April 2021

Published: 9 April 2021

Publisher's Note: MDPI stays neutral with regard to jurisdictional claims in published maps and institutional affiliations.

Copyright: (c) 2021 by the authors. Licensee MDPI, Basel, Switzerland. This article is an open access article distributed under the terms and conditions of the Creative Commons Attribution (CC BY) license (https:// creativecommons.org/licenses/by/ $4.0 /)$.
Abstract: With the increasing age of the population, the incidence of Parkinson's disease (PD) has increased exponentially. The development of novel therapeutic interventions requires an understanding of the involvement of senescent brain cells in the pathogenesis of PD. In this review, we highlight the roles played by microglia in the basal ganglia in the pathophysiological processes of PD. In PD, dopaminergic (DAergic) neuronal degeneration in the substantia nigra pars compacta (SNc) activates the microglia, which then promote DAergic neuronal degeneration by releasing potentially neurotoxic factors, including nitric oxide, cytokines, and reactive oxygen species. On the other hand, microglia are also activated in the basal ganglia outputs (the substantia nigra pars reticulata and the globus pallidus) in response to excess glutamate released from hyperactive subthalamic nucleiderived synapses. The activated microglia then eliminate the hyperactive glutamatergic synapses. Synapse elimination may be the mechanism underlying the compensation that masks the appearance of PD symptoms despite substantial DAergic neuronal loss. Microglial senescence may correlate with their enhanced neurotoxicity in the SNc and the reduced compensatory actions in the basal ganglia outputs. The dual roles of microglia in different basal ganglia regions make it difficult to develop interventions targeting microglia for PD treatment.

Keywords: synapse; phagocytosis; dopamine; basal ganglia; compensation; glutamate; subthalamic nucleus

\section{Introduction}

Parkinson's disease (PD) is a frequently diagnosed neurodegenerative disorder characterized by motor symptoms such as rigidity, bradykinesia, resting tremor, and postural instability, as well as nonmotor symptoms such as hyposmia, autonomic ataxia, and sleep disorders [1-5]. Pathologically, PD is characterized by the progressive degeneration of dopaminergic (DAergic) neurons in the substantia nigra (SN) pars compacta (SNc). The inclusion bodies in DAergic neurons, referred to as Lewy bodies, and their main protein component, $\alpha$-synuclein ( $\alpha$-Syn), are the prominent neuropathological features of this disease [6]. The recently established PROPAG-AGEING project aims to characterize the contribution of the aging process to the development of PD [7]. A previous study showed that aged rats exhibited a higher susceptibility to neurotoxin 6-hydroxydopamine (6-OHDA) to produce a PD model than young rats [8]. In recent decades, the incidence of PD has increased rapidly with the increasing age of the population [9]. Besides conventional symptomatic treatments such as L-DOPA, there is a need to develop new interventions to treat and prevent PD while addressing its pathophysiology.

This review focuses on the involvement of microglia in PD pathogenesis. Microglia are one of the major types of glial cells and the only cell type of mesodermal origin in the central nervous system (CNS). They comprise $5-10 \%$ of all CNS cells $[10,11]$ and are similar to macrophages and monocytes in the peripheral and circulatory systems $[12,13]$, except that some markers make microglia and blood-borne macrophages distinguishable [14-16]. Microglia can release various neurotoxic mediators [17]. In the pathophysiological processes of PD, microglia play a role in DAergic neuronal degeneration in the SNc [18-20]. 
SNc DAergic neurons undergo degeneration at least partly due to genetic mutations [21-24] or the formation of Lewy bodies, which contain oligomerized insoluble $\alpha$-Syn fibrils $[6,25]$. The degenerated neurons induce proinflammatory activation of microglia [26-28], leading to further degeneration of SNc DAergic neurons. A postmortem investigation of human brains showed that microglia transformed into reactive cells with proinflammatory phenotypes and expressed the major histocompatibility complex (MHC) class II antigen [19]. Thus, PD has neuroinflammatory disease characteristics, namely, the increased production of proinflammatory or neurotoxic factors by microglia in the $\mathrm{SNc}$, such as nitric oxide (NO); reactive oxygen species (ROS); glutamate; chemokines; and cytokines such as CCL2, interleukin-1 $\beta$ (IL-1 $\beta$ ), and tumor necrosis factor- $\alpha$ (TNF- $\alpha$ ) (Table 1) $[2,19,25,29-31]$. All these microglia-derived substances can negatively affect SNc DAergic neuronal survival. For example, fibrillary aggregates of $\alpha$-Syn enhance glutamate release by microglia, presumably resulting in the degeneration of DAergic neurons due to excitotoxic stress [32]. Microglia-activated astrocytes may mediate some of the neuroinflammatory reactions in PD pathogenesis [33-35].

In contrast, microglia also have neurotrophic or neuroprotective activities (Table 1) [36,37]. During inflammatory events, microglia can perform both proinflammatory and antiinflammatory functions. Microglia exert their anti-inflammatory actions partly due to antiinflammatory cytokines such as IL-10 and transforming growth factor- $\beta$ (TGF- $\beta$ ) $[38,39]$. Microglia phagocytose degenerated cells and materials in brain tissues, likely suppressing proinflammatory responses by microglia and blood-borne leukocytes [40,41].

Table 1. A list of neurotoxic and neuroprotective factors released by microglia.

\begin{tabular}{|c|c|}
\hline Neurotoxic and/or Proinflammatory Factors & Roles \\
\hline Interleukin-1 $\beta$ (IL-1 $\beta$ ) & typical pro-inflammatory cytokine $[42,43]$ \\
\hline Tumor necrosis factor- $\alpha$ (TNF- $\alpha)$ & typical pro-inflammatory cytokine $[42,43]$ \\
\hline $\mathrm{IL}-1 \alpha$ & typical pro-inflammatory cytokine, modulating astrocyte properties $[42,44]$ \\
\hline Glutamate & excitotoxin inducing neuronal death [45] \\
\hline Inducible nitric oxide synthases (iNOS) or NO & causing neuronal apoptosis $[36,46]$ \\
\hline Reactive oxygen species (ROS) & causing DNA damage and apoptosis [17] \\
\hline CCL2 & recruitment of circulating leukocytes [47] \\
\hline IL-5 & increasing nitrite levels [48] \\
\hline IL-8 & inducing release of pro-inflammatory cytokines and COX-2 [49] \\
\hline IL-12 & inducing nitric oxide synthase and activation of NF $\kappa B$ [50] \\
\hline IL-15 & inducing release of nitric oxide [51] \\
\hline IL-18 & inducing release of pro-inflammatory cytokines [52] \\
\hline Cyclooxygenase 2 (COX 2) & mediating microglial activation and neurodegeneration [53] \\
\hline Neuroprotective and/or anti-inflammatory factors & Roles \\
\hline insulin-like growth factor-1 (IGF-1) & inhibiting microglial ROS generation and suppressing M1 phenotype [17] \\
\hline platelet derived growth factor (PDGF) & inhibiting neuronal apoptosis PDGF [54] \\
\hline hepatocyte growth factor (HGF) & supporting regeneration of damaged neuron $[55,56]$ \\
\hline transforming growth factor- $\beta$ (TGF- $\beta$ ) & inhibiting activation of NF KB [38] \\
\hline brain derived growth factor (BDNF) & inhibiting the pro-inflammatory activation [57] \\
\hline arginase $1(\mathrm{Arg}-1)$ & inhibiting nitric oxide release [58] \\
\hline glial cell-derived neurotrophic factor (GDNF) & increasing enzymatic activity of superoxide dismutase [59] \\
\hline manganese-dependent superoxide dismutase (MnSOD) & suppressing oxidative stress [60] \\
\hline IL-3 & inhibiting apoptotic neuron death [61] \\
\hline IL-4 & increasing expression and release of IGF-1 [62] \\
\hline IL-10 & suppressing caspase-1-dependent IL- $1 \beta$ maturation [63] \\
\hline
\end{tabular}

The motor symptoms of PD do not appear until most SNc DAergic neurons have degenerated and the striatal dopamine (DA) levels have reduced [2,5,64-68], although there is a pre-motor or prodromal stage during which nonmotor symptoms such as hyposmia or depression but not motor symptoms are apparent [5]. Some compensatory mechanisms delay the onset of PD motor symptoms, and many hypotheses regarding these mechanisms have been proposed. Microglia may contribute to these compensatory mechanisms by eliminating subthalamic nucleus (STN)-derived hyperactive glutamatergic synapses. Such synapses become hyperactive in response to the reduced striatal DA levels (Figure 1). 


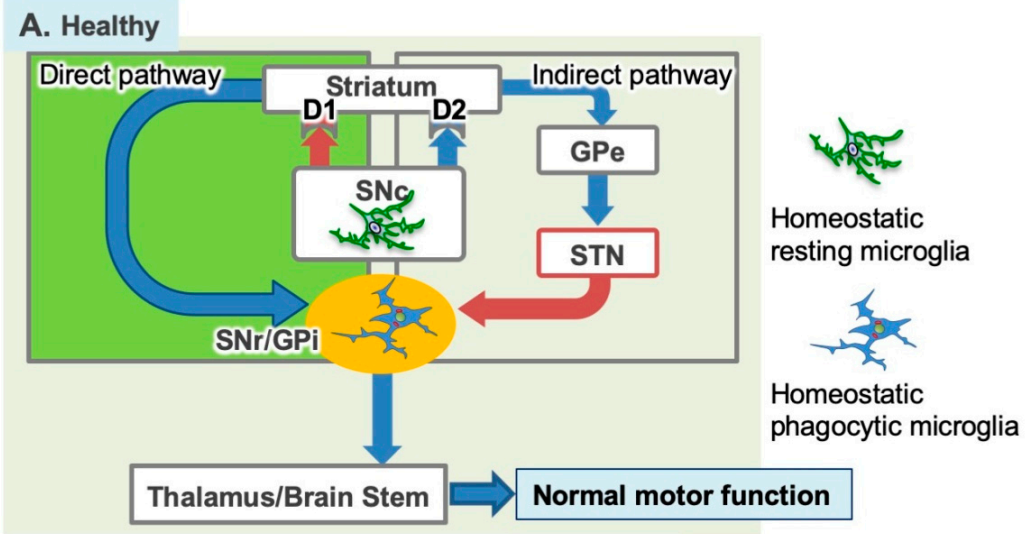

B. PD Pre-symptomatic period in the middle age

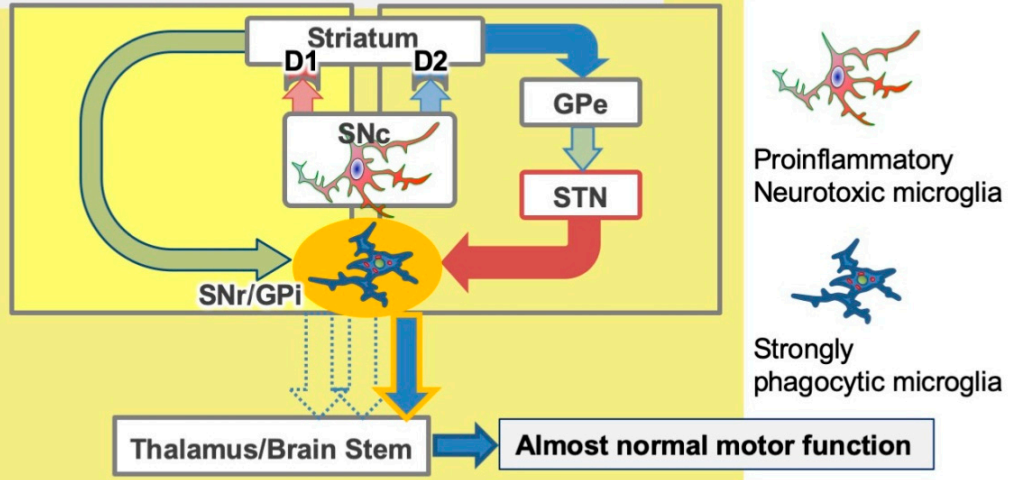

C. PD Symptomatic period in the elderly

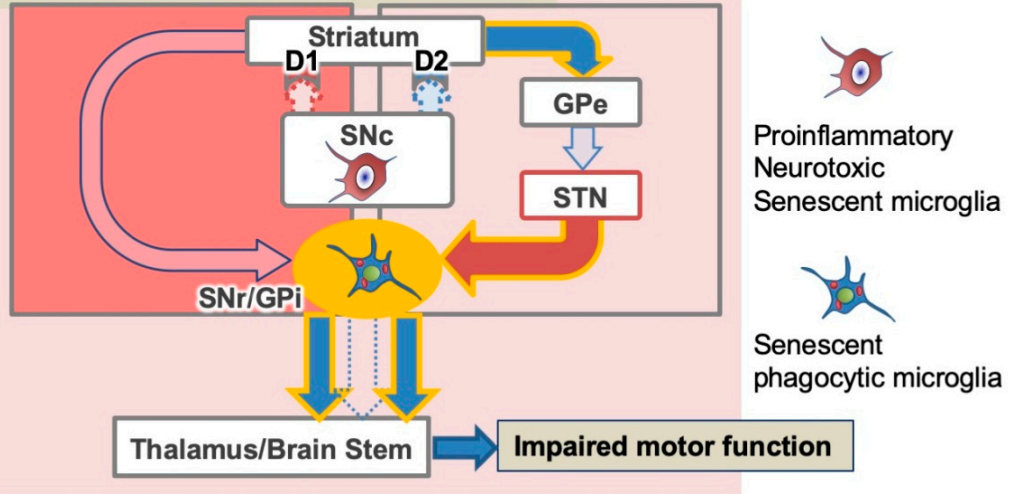

Excitatory : Glutamatargic, D1 receptor-DArgic Inhibitory: GABArgic, D2 receptor-DArgic

Figure 1. Hypothetical dual roles of microglia in the pathophysiology of Parkinson's disease (PD). (A) In the basal ganglia, homeostatic (or ramified) microglia may play a role in the maintenance of neural circuits both in the substantia nigra (SN) pars compacta (SNc) and basal ganglia outputs (SN pars reticulata ( $\mathrm{SNr}$ ) and globus pallidus pars interna (GPi)) in the normal young adult brain. STN; subthalamic nucleus, GPe; globus pallidus pars externa. (B) With age, SNc dopaminergic (DAergic) neuronal degeneration progresses slowly, and microglia undergo gradual proinflammatory activation. In the indirect pathway, DAergic neuronal degradation hyperactivates glutamatergic STN neurons. However, microglia in the basal ganglia outputs prevent the development of PD symptoms by eliminating hyperactive glutamatergic synapses from the STN. (C) Finally, most DAergic neurons die, and motor deficits appear. Microglia undergo senescent changes. In the SNc, microglia still exert harmful effects on viable DAergic neurons. In the basal ganglia outputs, senescent microglia cannot normalize the hyperactive synapses. 
In this review, we discuss the functional differences between the microglia in the SNc and those in the basal ganglia outputs, $\mathrm{SN}$ pars reticulata $(\mathrm{SNr})$, and globus pallidus pars interna (GPi) (Figure 1). Both regions project their GABAergic axons to both the thalamus and brain stem [69], and therefore, they are called basal ganglia outputs. SNc microglia may play a role in DAergic neuronal degeneration. Microglia in the SNc and basal ganglia outputs have distinct activation mechanisms. The microglia in the basal ganglia outputs may contribute to the compensatory mechanisms. Two neural circuits in the basal ganglia are of interest: the direct and indirect pathways (Figure 1A) [69-71]. The two circuits originate from two distinct GABAergic neuron populations in the striatum. In the direct pathway, GABAergic striatal neurons directly project their axons to the basal ganglia outputs. In the indirect pathway, another population of GABAergic neurons extend their axons to the globus pallidus pars externa (GPe). An optogenetic study clearly demonstrated that activation of the direct pathway enhances movement and that activation of the indirect pathway stops movement [71]. Because of their pro- and anti-inflammatory effects or their neurodestructive and neuroprotective roles, microglia are frequently described as "double-edged swords" [72-75]. However, in the present review, we use the term "dual roles" to refer to the distinct effects of microglia located in different regions of the basal ganglia on the pathophysiology of PD [68,76].

\section{Microglia in the SNc of Brains with PD}

\subsection{Aggravating Actions of Microglia}

Clinical and laboratory studies have revealed the presence of microglia with activated morphology with shortened processes and enlarged somata in the SNc of patients with PD. DAergic neuronal degeneration activates microglia in the SNc, which expresses and releases proinflammatory or neurotoxic mediators, ROS, glutamate, cytokines, and chemokines $[12,35,45,46,76]$ (Table 1). Chemokines recruit leukocytes in the circulation, thereby aggravating neuronal degeneration $[47,77]$. Proinflammatory activation of microglia is often considered a secondary change following neuronal degeneration [12]. However, proinflammatory microglia negatively affect neuronal survival before DAergic neuronal degradation [78-80]. Furthermore, lipopolysaccharide (LPS) injection in and around the SNc of animals induces the proinflammatory activation of microglia and subsequent DAergic neuronal death [2]. The addition of LPS to a neuron-microglial cell coculture causes microglia to release significant amounts of NO, resulting in neuronal death. Suppressing the activity or expression of LPS-induced inducible NO synthase (iNOS) using a NOS inhibitor, glucocorticoids [12,81], noradrenaline (NA) [82], or bromovalerylurea [46] prevented neuronal death. These observations suggest that activated microglia cause neurodegeneration independently of the neuron-based neurodegeneration mechanisms.

IL-1 $\beta$ and TNF- $\alpha$-expressing proinflammatory microglia may cause astrogliosis in the SNc, as shown in a 6-OHDA-induced PD model [18], although it remains unknown whether such astrogliosis protects DAergic neurons in the SNc. Even in PD animal models, astrocytes may play neuroprotective roles in the SNc by expressing ROS-scavenging enzymes and metallothionein [55] and by many other mechanisms [39,83-86]. However, neurotoxic astrocytes (called A1 astrocytes) were found to develop in the brains of patients with PD, presumably because activated microglia release IL- $1 \alpha$, TNF- $\alpha$, and complement C1q [33]. IL-1 $\alpha$ released from microglia may also stimulate aquaporin 4 expression in astrocytes, aggravating brain edema in ischemic brain insults [42]. Thus, activated microglia may enhance the degeneration of DAergic neurons in the SNc, partly by impeding such supportive actions of astrocytes for neurons.

The endogenous Toll-like receptor (TLR) ligands may trigger proinflammatory microglial activation. In a 1-methyl-4-phenyl-1,2,3,6-tetrahydropyridine (MPTP)-induced mouse PD model, TLR4-deficient mice were less vulnerable to MPTP intoxication than wild-type mice, and their SNc had fewer MHC class II antigen-expressing activated microglia [87]. Many other studies showed the involvement of TLRs in the activation of microglia in the SNc of PD-affected brains [88-90]. The endogenous TLR ligands in PD 
remain unknown. In ischemia- or injury-induced severe brain damage, damage-associated molecular patterns (DAMPs) released from degenerated neurons, other brain cells, and tissues act as endogenous TLR ligands [91,92]. TLR4 deficiency impairs the phagocytic response of microglia to insoluble intracellular inclusions formed in DAergic neurons or Lewy bodies containing $\alpha$-Syn [93]. $\alpha$-Syn activates proinflammatory microglia by inducing mitochondrial dysfunction or damage, which reduces ATP synthesis and leads to proinflammatory activation of the NLRP3 inflammasome [94]. Furthermore, $\alpha$-Syn induces the microglial proinflammatory reactions partly by activating the signal transducer and activator of transcription 3 [95]. Thus, the mechanism of proinflammatory microglial activation by $\alpha$-Syn in the SNc in PD may be distinct from that by DAMPs and other potential microglia activators such as neurons themselves [27], glutamate [68,96], or NA [97].

\subsection{Favorable Actions of Microglia in the SNc}

In PD, ROS play a role in SNc DAergic neuronal loss [98]. Activated microglia release ROS and NO [99]. However, microglia release fewer ROS than blood-borne macrophages [17]. In contrast, microglia markedly protect neurons from ROS-induced damage [36,37]. Microglia express neuroprotective factors such as IGF-1, platelet-derived growth factor (PDGF)-A, and hepatocyte growth factor (HGF) [12,46]. The neuroprotective properties of microglia are incompatible with their proinflammatory effects. The favorable phenotype may partly correspond to the so-called M2 phenotype of microglia. Microglia with proinflammatory properties have been called M1-polarized microglia, classically activated microglia, or simply M1 microglia. In contrast, microglia with neuroprotective, neurorestorative, and/or anti-inflammatory properties have been called M2 microglia or alternatively activated microglia [100]. However, researchers have questioned the M1 and M2 classification [38,41,101], partly because the expressions of markers used for this classification (such as IL-1 $\beta$ and CD86 for M1; and CD163 and IGF-1 for M2) are often inconsistent $[12,41,46]$. Microglia in the SNc of patients with PD may be regarded as M1type cells with neurotoxic effects because they release proinflammatory mediators and neurotoxic substances. Furthermore, their phagocytic activity may affect damaged neurons. Microglia can phagocytose even viable damaged cells by recognizing the apoptosis marker phosphatidylserine on the outer leaflet of the plasma membrane of damaged cells [102]. Phagoptosis, a form of cell death by phagocytosis, can affect viable cells. It aggravates ischemic brain insults and may occur in PD [103].

\subsection{Changes in Other Glial Cells}

We investigated the effects of a cytokine mixture containing granulocyte/macrophage colony-stimulating factor (GM-CSF) and IL-3, both of which are hematopoietic cytokines that stimulate bone marrow cells. IL-3 increases the expression of the antiapoptotic factor $\mathrm{Bcl}-\mathrm{xL}$ in neurons [61] and prevents ischemia-induced neuronal apoptosis. GM-CSF also suppresses the neurodegeneration of neurons in ischemic brain lesions [104]. The cytokine mixture of GM-CSF and IL-3 improved the morphological and functional outcomes of rats in a traumatic brain injury model [105], probably because it enhanced the proliferation of infiltrated blood-borne macrophages and increased the expression of their neurotrophic factors. The cytokines changed the morphology of rat primary microglia [106], increased their expression of the neuroprotective factors IGF-1 and HGF, and suppressed their expression of IL-1 $\beta$ and TNF- $\alpha$ [18] (Figure 2). Furthermore, the cytokines stimulated phagocytosis. When subcutaneously administered to rats with 6-OHDA-induced PD, the cytokine mixture inhibited DAergic neuronal loss, increased neuronal Bcl-xL expression, and suppressed microglial IL-1 $\beta$ expression in the SNc. SNc neurons and microglia both expressed cytokine receptors. These results indicate that activated microglia play pivotal roles in DAergic neuronal degeneration. The cytokine mixture creates an environment in which neurons can survive and the proinflammatory activation of microglia is avoidable (Figure 3). 
A

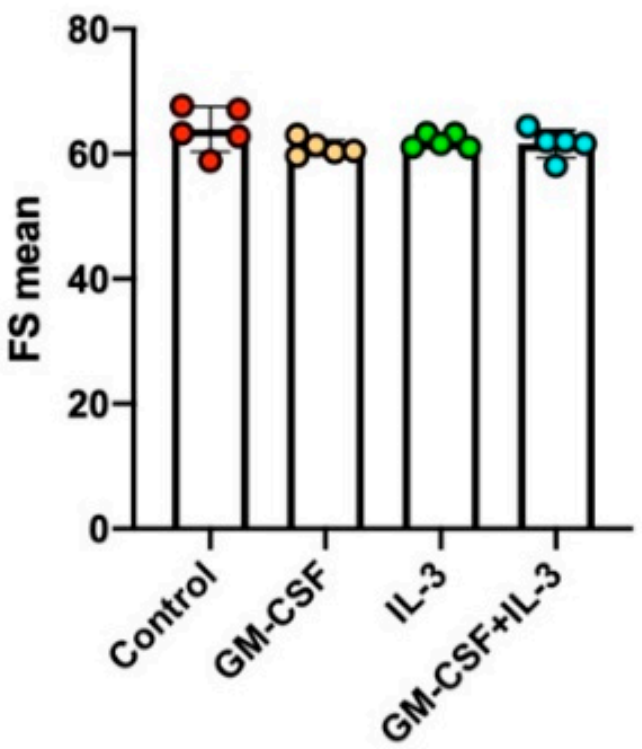

$\mathrm{Ca}$

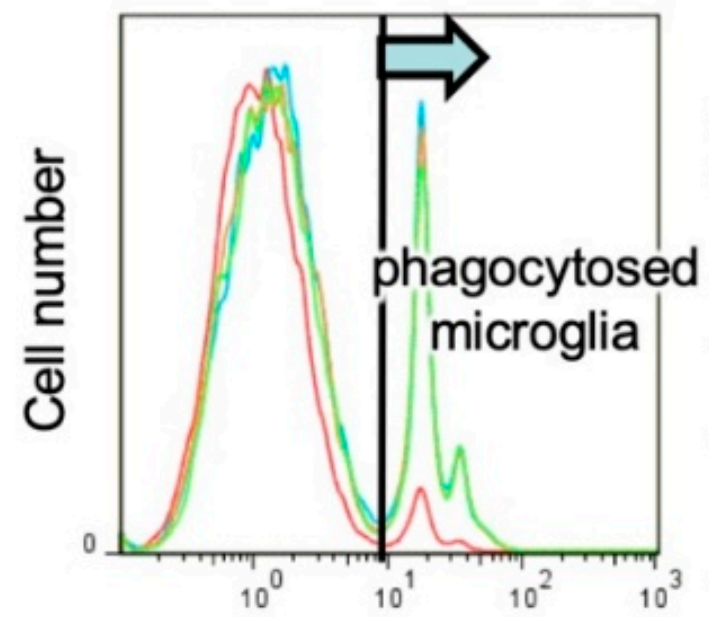

Fluorescence intensity

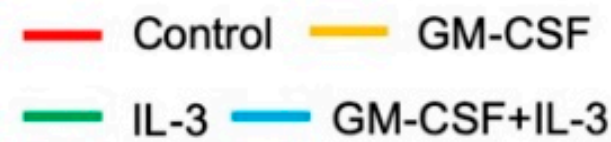

B

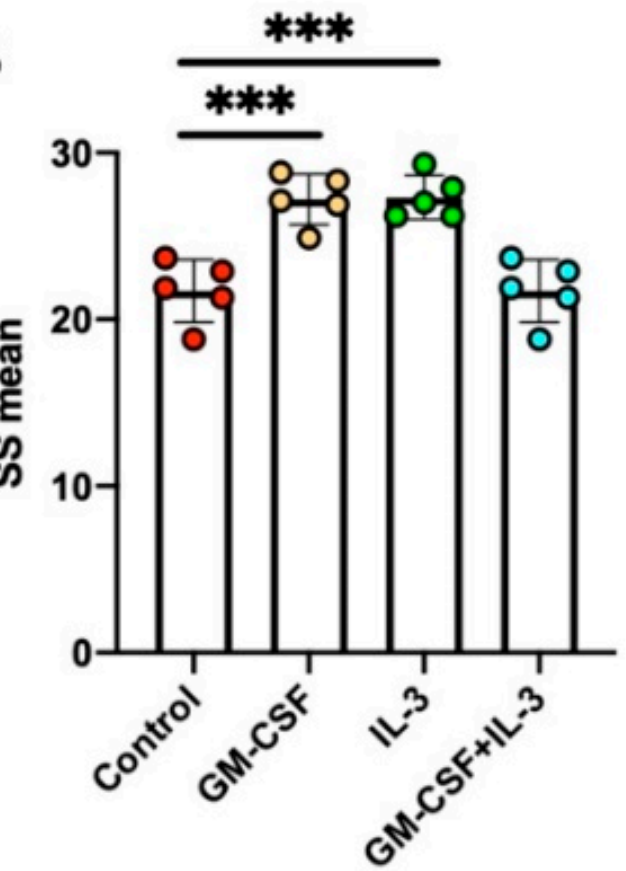

$\mathrm{Cb}$

***

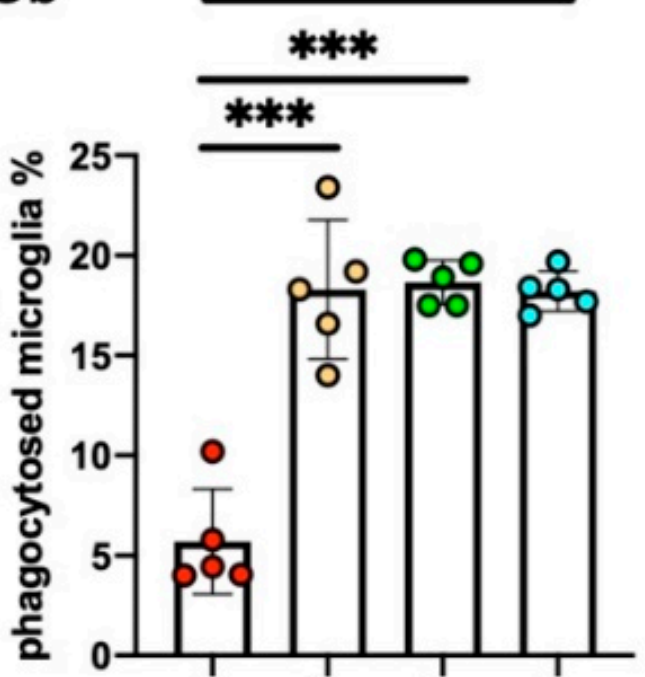
microglia. Effect of GM-CSF, IL-3, and GM-CSF + IL-3 on the morphology of rat primary microglia (forward scatter (FS; [A]) and side scatter (SS; [B])) and their phagocytic internalization of fluorescence-labeled latex beads (C, representative histogram (Ca) and the percentage of phagocytosed microglia $(\mathbf{C b}))$ as measured by flow cytometry. Data are expressed as mean \pm standard deviation. Unpaired two-tailed t-test. ${ }^{* * *} p<0.001$. Detailed information on the methodology for preparation of rat primary microglia culture and flow cytometry analyses is described elsewhere [96,107]. 


\section{A. Scenario to the development of PD}

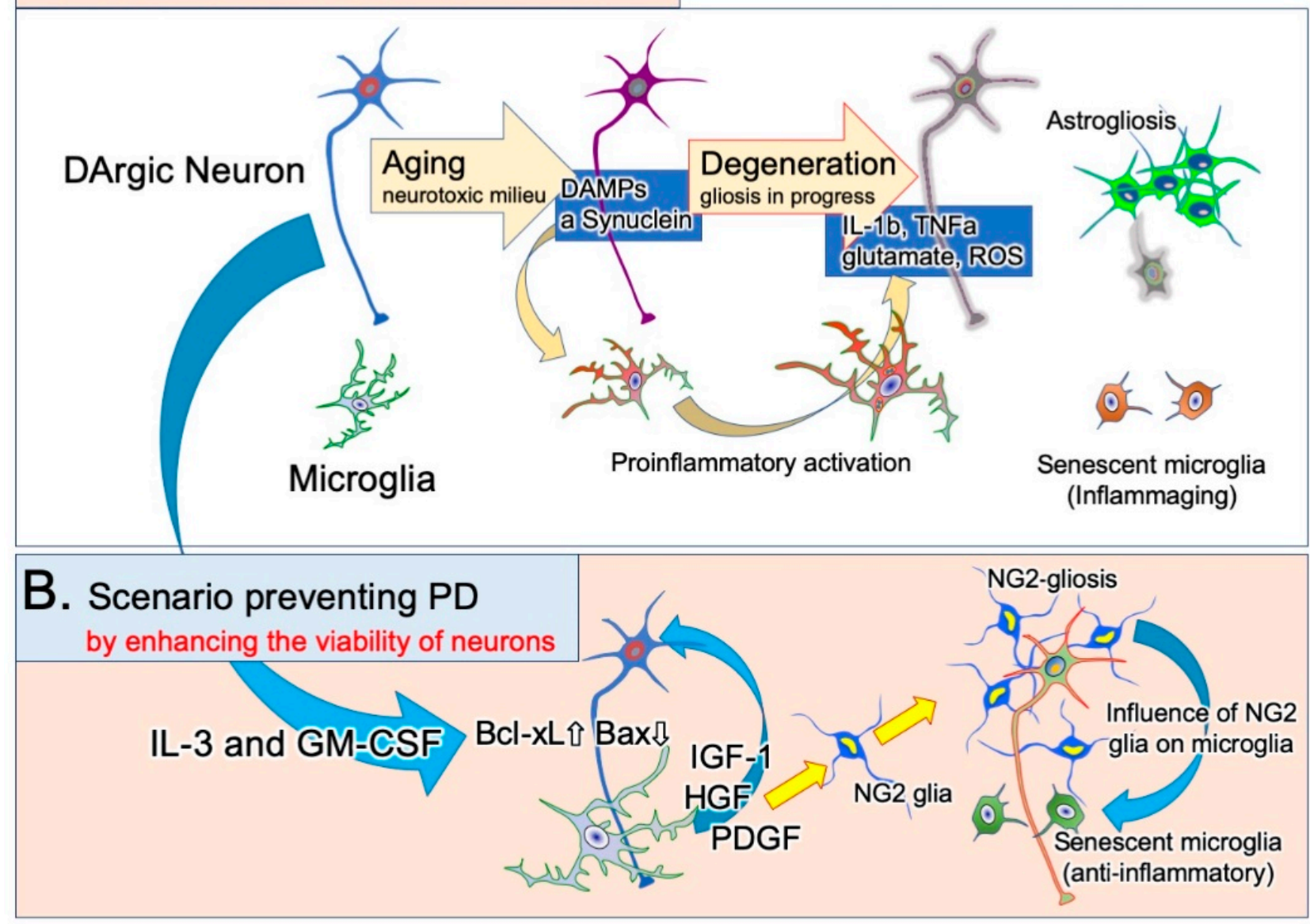

Figure 3. Neuronal viability and microglial phenotype changes in the SNc of a rat PD model. (A) With age, a toxic milieu forms around the DAergic neurons and adds to the intrinsic toxic mechanisms. Degenerating neurons generate damage-associated molecular patterns (DAMPs) and accumulate Lewy bodies containing $\alpha$-Syn fibrils within their somata, inducing proinflammatory microglia. Activated microglia further stimulate neuronal degeneration by releasing neurotoxic mediators. Finally, most DAergic neurons are lost and astrogliosis occurs. Senescent microglia may lose their neurotrophic properties but can still generate neurotoxic mediators. (B) The cytokine mixture (GM-CSF + IL-3) can inhibit progressive neurodegeneration by increasing the expression of the antiapoptotic factor Bcl-xL and suppressing the expression of the proapoptotic factor Bax. Then, microglial neurotoxic activation is avoided and activated microglia release more neurotrophic factors. Microglia-derived growth factors play neuroprotective roles and enhance the survival of DAergic neurons. Microglia-derived PDGF and HGF stimulate the proliferation of neural/glial antigen 2 (NG2) glia, resulting in NG2 gliosis. NG2 glia may be involved in maintaining the homeostatic functions of microglia. More detailed information is described elsewhere [18,108].

In addition to well-known glial cells such as astrocytes, oligodendrocytes, and microglia, the brain parenchyma contains neural/glial antigen 2 (NG2) glia or oligodendrocyte progenitor cells. NG2 is a type of chondroitin sulfate proteoglycan with a molecular weight of 290-300 kDa [109]. Although the roles of NG2 glia have not been completely elucidated [108,110-112], distinct responses in NG2 glia and astrocytes were noted in the above cytokine study [18] (Figure 3). PD model rats who received the vehicle had a higher number of degenerated DAergic neurons and marked astrogliosis. In contrast, the SNc of rats who received the cytokine mixture had a markedly higher number of NG2 glial cells and exhibited almost no astrogliosis. NG2 expression, but not that of the microglial marker Iba1, correlated with DAergic neuronal survival [18]. These results suggest that the primary change in PD pathology is the decrease in neuronal viability and the secondary change is microglial activation. Astrogliosis occurs after neuronal loss. When the Bcl-xL expression 
is elevated by DAergic neurons and neuronal viability is improved, microglia activation favors NG2 glial proliferation. NG2 glia expressing the HGF receptor cMet proliferate in response to HGF released by microglia [113]. NG2 glia also express receptors for binding PDGF, and their survival is dependent on PDGF [108].

\subsection{Interventions to Induce Favorable Actions of Microglia}

Many studies have demonstrated that suppressing the proinflammatory activation of microglia leads to their neuroprotective phenotypes. Minocycline, a tetracycline antibiotic, prevents the proinflammatory activation of microglia [114-116]. In an MPTP-induced mouse model of PD, minocycline blockade of microglial activation showed neuroprotective effects [114]. Minocycline suppressed the expression of various proinflammatory mediators and enzymes, such as IL- $1 \beta$, TNF- $\alpha$, IL-6, cyclooxygenase-2, and iNOS. Furthermore, minocycline increased the expression of the anti-inflammatory cytokine IL-10 [116]. These effects are characteristic of minocycline, and other tetracyclines have much weaker effects on microglia. Based on the favorable effects of minocycline on activated microglia, clinical trials have attempted to determine whether it has ameliorative effects on PD. However, no satisfactory results have been obtained $[117,118]$.

Glucocorticoids have strong immunosuppressive effects on microglia [12,46,81]. Dexamethasone (Dex), a synthetic glucocorticoid, prevents the release of NO by LPS-treated rat primary microglia, and it is much more efficient than minocycline [12]. Furthermore, Dex prevents the LPS-induced expression of IL- $1 \beta, \mathrm{TNF}-\alpha$, and IL- 6 and increases the expression of the neuroprotective factors IGF-1 and HGF. These results suggest that glucocorticoids induce M2-like phenotypes in microglia. Besides, in animal PD models, glucocorticoids, including Dex, can exert protective effects on SNc DAergic neurons and ameliorate motor deficits. Bromovalerylurea (BU), a type of hypnotic/sedative containing bromine, has a strong anti-inflammatory action $[17,46,119,120]$. Its immunosuppressive effect is as strong as that of Dex, and it increases the expression of IGF-1, PDGF, and HGF and suppresses the expression of IL-1 $\beta$, TNF- $\alpha$, iNOS, and the proinflammatory transcription factors called interferon regulatory factors. Oral administration of BU to 6-OHDA-induced PD model rats suppressed SNc DAergic neuronal degeneration and markedly ameliorated motor deficits [46]. The anti-inflammatory actions of BU may correlate with the suppression of glycolysis and mitochondrial metabolism, which reduce ATP production [17,119]. BU also suppresses LPS-induced phosphorylation of STAT1.

However, animal models produce acute neurodegeneration on an hourly or daily scale, which differs from the slow process of the neurodegeneration of clinical PD, which occurs on a yearly scale. The contribution of microglial inflammatory responses in clinical PD cases is still unclear. Although PD models are generally established in young animals, clinical PD usually affects the elderly, and researchers must consider the senescent changes in cells, as discussed next. Furthermore, activated microglia may have a role in the compensatory mechanisms (Figure 1), and Dex-induced microglial suppression may at least transiently aggravate the motor deficits [68]. Moreover, even if Dex, BU, and other anti-inflammatory agents and cytokines inhibit the neuroinflammatory processes, it would be difficult for patients with PD to continue taking the agents for decades because of their presumable side effects. These considerations highlight the difficulty in translating laboratory findings on anti-inflammatory drugs into clinical practice.

\section{Microglia in the Basal Ganglia Outputs}

\subsection{Compensatory Mechanisms in PD}

It is well-established that the severity of DAergic neuronal loss does not linearly correlate with the severity of PD motor symptoms, which become apparent only after a substantial loss of SNc DAergic neurons and the subsequent marked reduction in striatal DA levels. The estimated threshold for the degenerative changes is a $50-60 \%$ loss of SNc DAergic neurons and a 70-80\% reduction in the striatal DA levels in humans as well as in PD animal models $[2,64,65,121,122]$. Two behavioral tests, the cylinder test and forepaw 
adjustment steps test, are used to evaluate the motor deficits in the forepaws of the rat hemi-PD model and are the most sensitive to decreases in the striatal DA levels. Yet, they detect motor deficits only when the DA levels are $<50 \%$ of the normal level. Thus, the compensatory mechanisms may suppress the appearance of motor symptoms.

Some compensatory mechanisms have been proposed to explain what prevents the decreased striatal DA levels from causing abnormalities in the neural circuits [64,65,122]. One of the probable compensatory mechanisms is the increased release of DA or the enhanced axonal sprouting by viable neurons. An increased DA turnover may also contribute to the compensation. Many other mechanisms, such as the involvement of enkephalin and increased sensitivity of D2 receptors, have been postulated. In relation to the increased sensitivity of dopamine receptors, apomorphine test should be noted, which is a common way to check the validity of the 6-OHDA-induced rat hemi-PD model. Apomorphine is a nonselective dopamine agonist used for the treatment of advanced PD [123], and it causes hemi-PD model rats to rotate instead of walking straight by overstimulating the hypersensitive dopamine receptor [2]. Microglia also play a part in the compensatory mechanisms (Figure 1).

\subsection{Activated Microglia in the Basal Ganglia Outputs}

In a previous study, while observing microglial activation in the brains of a rat $\mathrm{PD}$ model, we found that microglial activation was more prominent in the SNr and GPi than in the SNc (Figure 4) [68]. In PD, the basal ganglia outputs where GABAergic neurons localize have no apparent neuronal degeneration. The microglial activation was characterized by increased expression of CD11b immunoreactivity, a component of complement C3b receptor, and CD68, a phagocyte marker (Figure 4). Furthermore, the activated microglia characteristically expressed NG2, although it is a marker for NG2 glia. NG2 is often expressed by blood-borne macrophages as well as activated microglia, both of which possess increased phagocytic activity $[39,40,109]$. The $\mathrm{NG}^{+}$activated microglia adhered to the surface of GABAergic neurons in the basal ganglia outputs and engulfed synaptic elements. The engulfed synapses were STN-derived glutamatergic synapses located in the indirect pathway in the neural circuits in the basal ganglia (Figure 1). The decreased release of DA from SNc neurons hyperactivates STN. Microglia express various types of glutamate receptors [68,124-126], and glutamate can induce changes in their morphology [127] and activate their phagocytic functions $[68,96]$. Normally, none of the GABAergic neurons in the basal ganglia outputs are degenerated in PD brains; therefore, they do not directly affect the activities of microglia. The effects of glutamate neurotransmission may also be indirectly mediated to microglia by the increased extracellular concentration of ATP $[127,128]$.

SNc DAergic neuronal loss activates striatal GABAergic neurons in the indirect pathway (Figure 1). The activated GABAergic neurons then inactivate GABAergic neurons in the GPe and hyperactivate glutamatergic neurons in the STN. Excessive STN neuron activity causes glutamate spillover from the hyperactive glutamatergic synapses in the basal ganglia outputs, which stimulates the phagocytic activity of microglia [68,96]. In turn, microglia eliminate the hyperactive glutamatergic synapses (Figure 1B). Thus, activated microglia in the basal ganglia outputs at least partially normalize the abnormality in the neural circuits in the basal ganglia in PD. This is another probable compensatory mechanism involving microglia.

Functional neurosurgery treats PD using deep brain stimulation (DBS) to suppress the activity of the hyperactive STN. STN-DBS reduces motor symptoms in patients with PD and improves their quality of life, making STN the current primary target of DBS [129-131]. The effects of activated microglia in the basal ganglia outputs may be similar to those caused by STN-DBS. During the presymptomatic stages of PD, when DAergic neuronal degeneration progresses inconspicuously, microglia may prevent the appearance of $\mathrm{PD}$ symptoms by eliminating hyperactive STN-derived synapses (Figures 1B and 4C). Why, then, is neurosurgical STN-DBS effective in patients with PD despite the DBS-like effects of 
microglia? We speculate that microglial senescence causes the appearance of PD symptoms in the elderly (Figure 1C).
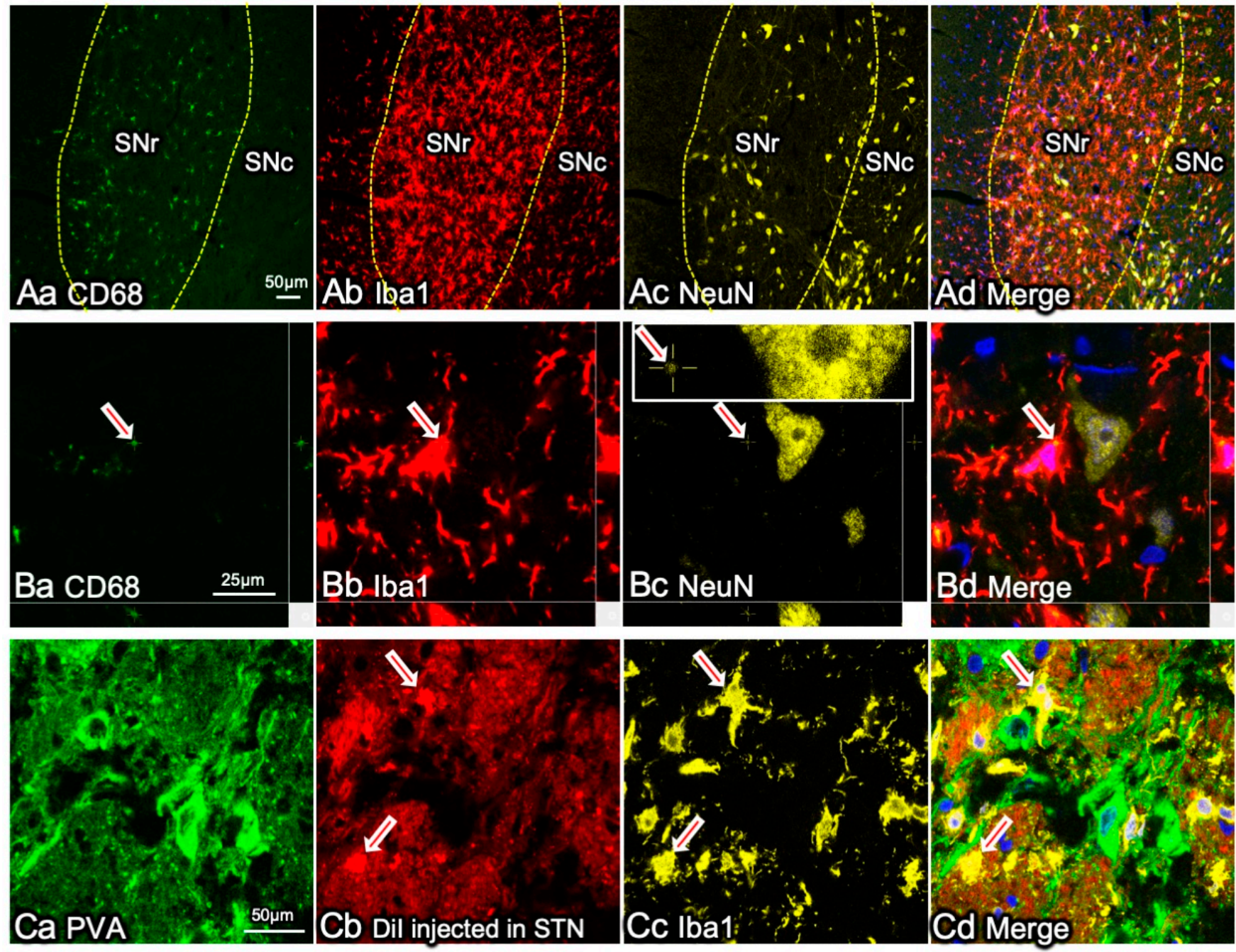

Figure 4. Microglial activation is more pronounced in SNr and GPi than in SNc. (A) Activated microglia with elevated CD68 expression are more densely present in SNr rather than in SNc in a rat 6-OHDA-induced PD model brain. The cryosection was triple-immunostained with antibodies to a phagosome marker CD68 (Aa), a microglial marker Iba1 (Ab), and a neuronal marker $\mathrm{NeuN}$ (Ac). (B) An activated microglial cell in $\mathrm{SNr}$ has a CD68 ${ }^{+}$phagosome (arrows) in its cytoplasm that contains $\mathrm{NeuN}^{+}$materials (an arrow in inset in $(\mathbf{B c})$ ), indicating that the cell phagocytosed some neuronal elements. (C) Activated microglia in the GPi phagocytosed nerve terminals from the STN. Lipophilic red fluorescent DiI was injected into the STN. The DiI was transported on the axonal membrane to the GPi. Activated Iba1 ${ }^{+}$microglial cells internalized DiI (arrowheads in $\mathbf{C b}, \mathbf{C c}$, and $\mathbf{C d}$ ). GABAergic neurons are identified with immunoreactivity to parvalbumin (PVA; Ca). The methodology for these results is described elsewhere [68].

\subsection{Problems Associated with Anti-Inflammatory Drugs That Suppress Microglial Phagocytosis}

Chronic administration of a synthetic glucocorticoid such as Dex or BU effectively suppresses microglia-mediated DAergic neuronal degeneration in animal PD models. In fact, after ceasing administration, the PD model rats displayed better motor functions than the control rats $[12,46]$. However, we found that a high dose of Dex transiently aggravated the motor symptoms of rats with 6-OHDA-induced PD, even if it ameliorated the overall outcome [68]. Besides its anti-inflammatory effects, Dex strongly suppresses the phagocytic activity of primary cultured rat microglia and CD68 expression by microglia in the $\mathrm{SNr}$ of PD model rats. These observations suggest that microglia have dual roles in PD 
pathophysiology (Figure 1): aggravating effects in the SNc through their proinflammatory actions, thereby enhancing DAergic neuronal degeneration, and favorable effects in the basal ganglia outputs by normalizing the glutamatergic neurotransmission through the phagocytosis of the hyperactive synapses. Thus, pharmacological interventions that suppress microglial activities may not succeed for two reasons. First, because after most neurons have degenerated, it is too late to start a clinical intervention. Second, because they prevent the favorable phagocytic actions of microglia in the basal ganglia outputs. Stress conditions increase the release of glucocorticoids from the adrenal glands [11]. Emotional or psychological stress can transiently worsen the motor symptoms of patients [132] and animals [133]. The stress-induced aggravation of motor symptoms at least partly correlates with the elevation of circulating glucocorticoid levels, which impairs the compensatory actions of microglia in the basal ganglia outputs.

In contrast, the cytokines IL-3 and GM-CSF increase microglial phagocytic activity (Figure 2), whereas they suppressed the proinflammatory activation of microglia in the SNc in a rat PD model [18]. Although chronically administering the cytokine mixture to patients with PD may be impossible, this is how an ideal therapeutic intervention should affect microglia.

\section{Senescent Changes of Microglia and PD}

Aging induces profound changes in microglial morphology and functions [134]. In the mouse brain, aged or senescent microglia have characteristic short, thick processes and enlarged cell bodies, as well as showing increased production of inflammatory cytokines and ROS and impaired phagocytic and lysosomal activity. Overall, senescent changes promote microglial neurotoxicity. Similarly, in the human brain, aged dystrophic microglia display spherical swelling and reduced arborization of processes [135], endoplasmic reticulum dilatation, and an abundance of lipofuscin deposits [136,137]. Transcriptomic analysis of sorted microglia in aged human brains showed a high expression of cell adhesion, axonal guidance, and cell surface receptor genes [138]. Increased expression of MHC class II [139,140], CD68 [136,141], and TLRs [142] are common features of aged microglia. A study reported a subset of microglia with inflammatory phenotypic signatures and high CD11c and CD14 in aged mice [143]. The senescent changes of microglia cause "inflammaging", a chronic, low-grade inflammation regarded as the most common brain feature in aged individuals [144]. From neuroprotective cells, aged microglia become neurotoxic cells that cause inflammaging [145]. The phenotypic changes of aging microglia may correlate with the PD symptom onset by inducing SNc DAergic neuronal degeneration and also by reduced phagocytic elimination of hyperactive glutamatergic synapses from STN (Figure 1).

Besides the functional features of individual microglia, aging affects the number of microglia. An immunohistochemical study on aged mouse brains showed that the number of Iba $1^{+}$microglia was drastically decreased and that their distribution pattern was uneven and unbranched [146]. We also observed microglial phenotype changes in the aged rat prefrontal cortex using flow cytometry (Figure 5). Microglia from 22-month-old rats had higher forward scatter (FS; cell size index) and side scatter (SS; granularity index) values than those from 2-month-old rats. Therefore, microglia in aged brains are larger and retain higher contents of intracellular phagosomes or lysosomes than those in young brains. Figure 5 also shows the increased expression of the phagocytosis-related molecules CD11b, CD68, and NG2, as well as proinflammatory phenotype-related markers CD86 and CD45 in aged microglia [147]. Nevertheless, the overall phagocytic activity of aged microglia declines, and a reduced ability to eliminate hyperactive synapses in the basal ganglia outputs may allow the motor disorders of PD to appear [148]. 

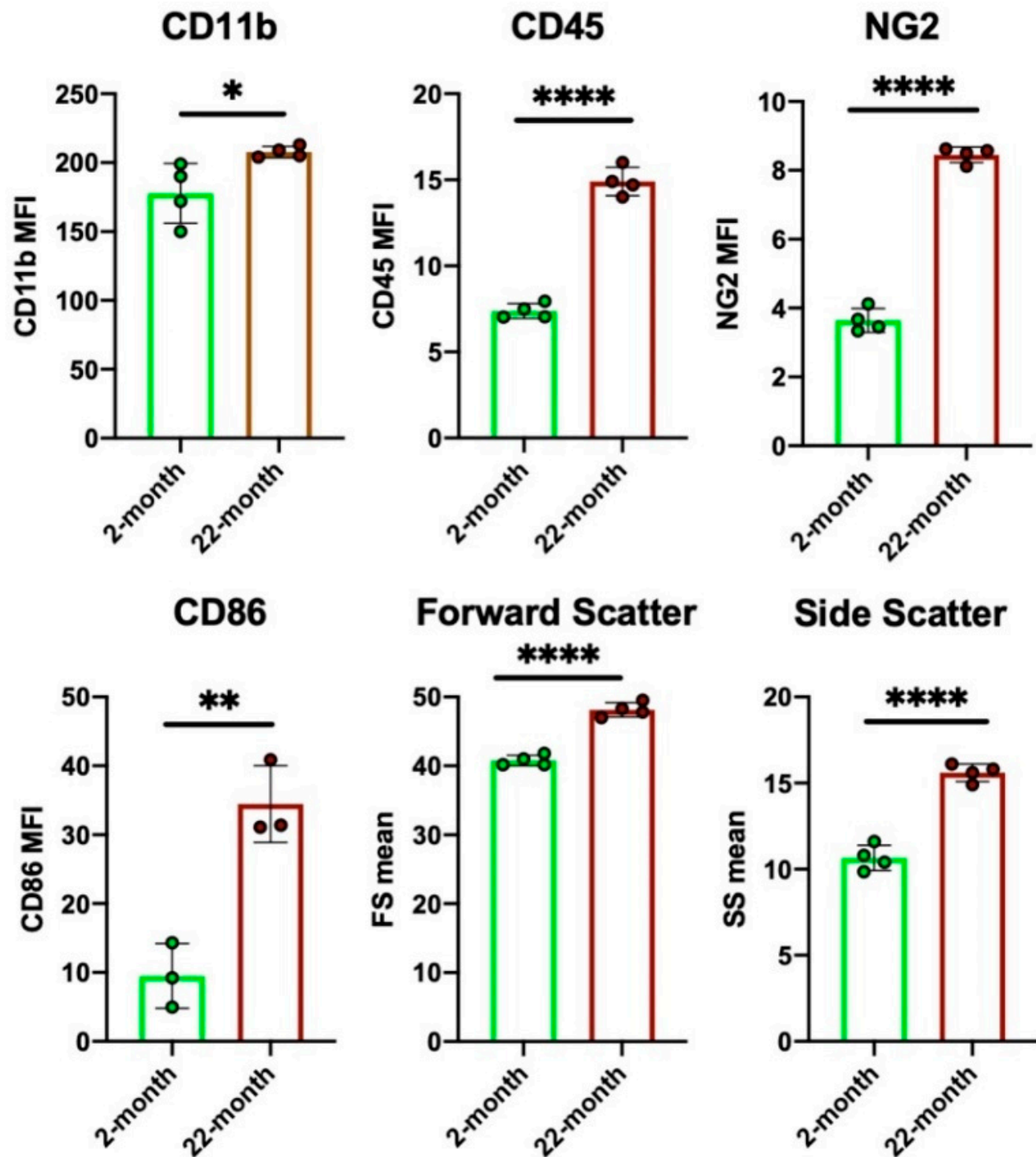

Side Scatter

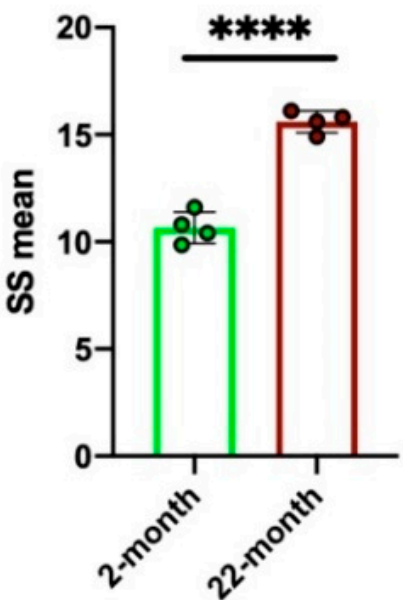

Figure 5. Senescent changes of microglia, as revealed by flow cytometry. Brain cells in the prefrontal cortices of 2- and 22-month-old male Wistar rats were enzymatically dissociated and subjected to flow cytometry analyses. Microglial cells in the 22-month-old rat brains showed higher CD11b, CD45, NG2, and CD86 expression than those in the 2-month-old rat brains. Furthermore, the senescent microglia had higher forward scatter (FS) and side scatter (SS) values, implying that they had larger and more granular somata than those in the young rat brains. Data are expressed as the mean \pm SD. Unpaired two-tailed t-test. ${ }^{*} p<0.05,{ }^{* *} p<0.01,{ }^{* * * *} p<0.0001$. Detailed information on the methodology is presented elsewhere [96].

Similar to DAergic neurons, noradrenergic neurons in the locus coeruleus degenerate with age [149]. Although there is much debate [97], NA inhibits microglial proinflammatory activation $[82,150]$ at least partly by increasing intracellular cAMP levels $[150,151]$. In Alzheimer's disease, activated microglia accelerate neuronal loss [152]. Microglial activation may correlate with the decrease in brain NA levels due to the senescent changes of locus coeruleus neurons [149]. Furthermore, aging gradually increases the number of degenerating neurons, resulting in a massive loss of CD200 or CX3CL1, which inhibits the proinflammatory activation of adjacent microglia [153].

\section{Conclusions and Prospects}

Many investigations have focused on the pathophysiological contribution of SNc microglia to PD. Therefore, microglia are recognized as promoters of DAergic neuronal death, and researchers have attempted to use anti-inflammatory agents for PD treatment. However, as introduced in detail in this review, microglia may play critical homeostatic roles to 
maintain motor functions by eliminating STN-derived hyperactive glutamatergic synapses. Synaptic elimination by microglia through phagocytosis occurs in the developing brain and the normal mature brain [154-156]. A deficiency in synaptic elimination by microglia may cause developmental behavioral disorders such as autism spectrum disorder [76]. A deficiency in the mature brain may correlate with sleep/wake cycle disorders [96], memory function disorders [157], and psychiatric or stress-related mental disorders [76,158,159]. The most significant role of microglia in the mature brain with almost intact blood-brain barrier (BBB) functions might be the maintenance of neural circuits through synapse phagocytosis. BBB disruption allows the massive infiltration of various types of factors, including cytokines and amino acids $[68,96,106,107]$, resulting in the proliferation and proinflammatory activation of microglia. Yet, such apparent BBB breakdown does not occur in PD, and DAergic neuronal degeneration progresses slowly. The proinflammatory activation of SNc microglia in PD is less pronounced than that in stroke [39] or brain injury [17,160]. Microglial activation is stronger in the SNr or GPi than in the SNc, suggesting that microglia prevent PD onset rather than worsening PD. Progressive DAergic neuronal degeneration is an inevitable physiological change that occurs with aging, and it seems counterintuitive to assume that microglia primarily aggravate neuronal and neural circuit damage. A greater focus on the favorable effects of microglia on homeostasis in the brain functions would help develop new therapeutic avenues for PD.

Author Contributions: M.E.C. and J.T. drafted the manuscript. Y.K. helped with preparation of Figures. J.T. revised extensively the manuscript. All authors have read and agreed to the published version of the manuscript.

Funding: This APC was funded by Japan Society for the Promotion of Science, KAKENHI [Grant-inAid for Scientific Research (C) grant number 20K06856].

Institutional Review Board Statement: All animal experiments were conducted in accordance with the Guidelines of the Ethics Committee for Animal Experimentation of Ehime University, Japan (approval numbers; 05U31-2 and 05U32-2).

Informed Consent Statement: Not applicable.

Data Availability Statement: Not applicable.

Acknowledgments: This work was funded by KAKENHI-20K21465 to JT; KAKENHI-20K06856 to MEC from Japan Society for the Promotion of Science.

Conflicts of Interest: The authors declare no conflict of interest.

\section{References}

1. Jankovic, J. Parkinson's disease: Clinical features and diagnosis. J. Neurol. Neurosurg. Psychiatry 2008, 79, 368-376. [CrossRef]

2. Miyanishi, K.; Choudhury, M.E.; Watanabe, M.; Kubo, M.; Nomoto, M.; Yano, H.; Tanaka, J. Behavioral tests predicting striatal dopamine level in a rat hemi-Parkinson's disease model. Neurochem. Int. 2019, 122, 38-46. [CrossRef] [PubMed]

3. Ando, R.; Choudhury, M.E.; Yamanishi, Y.; Kyaw, W.T.; Kubo, M.; Kannou, M.; Nishikawa, N.; Tanaka, J.; Nomoto, M.; Nagai, M. Modafinil alleviates levodopa-induced excessive nighttime sleepiness and restores monoaminergic systems in a nocturnal animal model of Parkinson's disease. J. Pharmacol. Sci. 2018, 136, 266-271. [CrossRef] [PubMed]

4. Kalia, L.V.; Lang, A.E. Parkinson's disease. Lancet 2015, 386, 896-912. [CrossRef]

5. Cova, I.; Priori, A. Diagnostic biomarkers for Parkinson's disease at a glance: Where are we? J. Neural Transm. 2018, 125, 1417-1432. [CrossRef] [PubMed]

6. Dickson, D.W.; Braak, H.; Duda, J.E.; Duyckaerts, C.; Gasser, T.; Halliday, G.M.; Hardy, J.; Leverenz, J.B.; del Tredici, K.; Wszolek, Z.K.; et al. Neuropathological assessment of Parkinson's disease: Refining the diagnostic criteria. Lancet Neurol. 2009, 8, 1150-1157. [CrossRef]

7. Pirazzini, C.; Azevedo, T.; Baldelli, L.; Bartoletti-Stella, A.; Calandra-Buonaura, G.; Molin, A.D.; Dimitri, G.M.; Doykov, I.; GómezGarre, P.; Hägg, S.; et al. A geroscience approach for Parkinson's disease: Conceptual framework and design of PROPAG-AGEING project. Mech. Ageing Dev. 2021, 194, 111426. [CrossRef]

8. Barata-Antunes, S.; Teixeira, F.G.; Mendes-Pinheiro, B.; Domingues, A.V.; Vilaça-Faria, H.; Marote, A.; Silva, D.; Sousa, R.A.; Salgado, A.J. Impact of Aging on the 6-OHDA-Induced Rat Model of Parkinson's Disease. Int. J. Mol. Sci. 2020, 21, 3459. [CrossRef] 
9. Driver, J.A.; Logroscino, G.; Gaziano, J.M.; Kurth, T. Incidence and remaining lifetime risk of Parkinson disease in advanced age. Neurology 2009, 72, 432-438. [CrossRef]

10. Kettenmann, H.; Hanisch, U.-K.; Noda, M.; Verkhratsky, A. Physiology of Microglia. Physiol. Rev. 2011, 91, 461-553. [CrossRef]

11. Picard, K.; St-Pierre, M.-K.; Vecchiarelli, H.A.; Bordeleau, M.; Tremblay, M.-È. Neuroendocrine, neuroinflammatory and pathological outcomes of chronic stress: A story of microglial remodeling. Neurochem. Int. 2021, 145, 104987. [CrossRef]

12. Tanaka, J. Favorable and unfavorable roles of microglia and macrophages in the pathologic central nervous system. Neuroimmunol. Neuroinflamm. 2020, 2020, 73-91. [CrossRef]

13. Abe, N.; Nishihara, T.; Yorozuya, T.; Tanaka, J. Microglia and Macrophages in the Pathological Central and Peripheral Nervous Systems. Cells 2020, 9, 2132. [CrossRef]

14. Konishi, H.; Kobayashi, M.; Kunisawa, T.; Imai, K.; Sayo, A.; Malissen, B.; Crocker, P.R.; Sato, K.; Kiyama, H. Siglec-H is a microglia-specific marker that discriminates microglia from CNS-associated macrophages and CNS-infiltrating monocytes. Glia 2017, 65, 1927-1943. [CrossRef]

15. Bennett, M.L.; Bennett, F.C.; Liddelow, S.A.; Ajami, B.; Zamanian, J.L.; Fernhoff, N.B.; Mulinyawe, S.B.; Bohlen, C.J.; Adil, A.; Tucker, A.; et al. New tools for studying microglia in the mouse and human CNS. Proc. Natl. Acad. Sci. USA 2016, 113, E1738-E1746. [CrossRef]

16. Satoh, J.-I.; Kino, Y.; Asahina, N.; Takitani, M.; Miyoshi, J.; Ishida, T.; Saito, Y. TMEM119 marks a subset of microglia in the human brain. Neuropathology 2015, 36, 39-49. [CrossRef]

17. Abe, N.; Choudhury, M.E.; Watanabe, M.; Kawasaki, S.; Nishihara, T.; Yano, H.; Matsumoto, S.; Kunieda, T.; Kumon, Y.; Yorozuya, T.; et al. Comparison of the detrimental features of microglia and infiltrated macrophages in traumatic brain injury: A study using a hypnotic bromovalerylurea. Glia 2018, 66, 2158-2173. [CrossRef] [PubMed]

18. Choudhury, M.E.; Sugimoto, K.; Kubo, M.; Nagai, M.; Nomoto, M.; Takahashi, H.; Yano, H.; Tanaka, J. A cytokine mixture of GM-CSF and IL-3 that induces a neuroprotective phenotype of microglia leading to amelioration of (6-OHDA)-induced Parkinsonism of rats. Brain Behav. 2011, 1, 26-43. [CrossRef]

19. McGeer, P.L.; Itagaki, S.; Boyes, B.E.; McGeer, E.G. Reactive microglia are positive for HLA-DR in the substantia nigra of Parkinson's and Alzheimer's disease brains. Neurology 1988, 38, 1285. [CrossRef] [PubMed]

20. McGeer, P.L.; McGeer, E.G. Inflammation and neurodegeneration in Parkinson's disease. Parkinsonism Relat. Disord. 2004, 10, S3. [CrossRef] [PubMed]

21. Liu, G.H.; Qu, J.; Suzuki, K.; Nivet, E.; Li, M.; Montserrat, N.; Yi, F.; Xu, X.; Ruiz, S.; Zhang, W.; et al. Progressive degeneration of human neural stem cells caused by pathogenic LRRK2. Nature 2012, 491, 603-607. [CrossRef] [PubMed]

22. Healy, D.G.; Falchi, M.; O'Sullivan, S.S.; Bonifati, V.; Durr, A.; Bressman, S.; Brice, A.; Aasly, J.; Zabetian, C.P.; Goldwurm, S.; et al. Phenotype, genotype, and worldwide genetic penetrance of LRRK2-associated Parkinson's disease: A case-control study. Lancet Neurol. 2008, 7, 583-590. [CrossRef]

23. Satake, W.; Nakabayashi, Y.; Mizuta, I.; Hirota, Y.; Ito, C.; Kubo, M.; Kawaguchi, T.; Tsunoda, T.; Watanabe, M.; Takeda, A.; et al Genome-wide association study identifies common variants at four loci as genetic risk factors for Parkinson's disease. Nat. Genet. 2009, 41, 1303-1307. [CrossRef] [PubMed]

24. Simón-Sánchez, J.; Schulte, C.; Bras, J.M.; Sharma, M.; Gibbs, J.R.; Berg, D.; Paisan-Ruiz, C.; Lichtner, P.; Scholz, S.W.; Hernandez, D.G.; et al. Genome-wide association study reveals genetic risk underlying Parkinson's disease. Nat. Genet. 2009, 41, 1308-1312. [CrossRef]

25. Castro-Sánchez, S.; García-Yagüe, Á.J.; López-Royo, T.; Casarejos, M.; Lanciego, J.L.; Lastres-Becker, I. Cx3cr1-deficiency exacerbates alpha-synuclein-A53T induced neuroinflammation and neurodegeneration in a mouse model of Parkinson's disease. Glia 2018, 66, 1752-1762. [CrossRef]

26. Biber, K.; Neumann, H.; Inoue, K.; Boddeke, H.W.G.M. Neuronal 'On' and 'Off' signals control microglia. Trends Neurosci. 2007, 30, 596-602. [CrossRef]

27. Sudo, S.; Tanaka, J.; Toku, K.; Desaki, J.; Matsuda, S.; Arai, T.; Sakanaka, M.; Maeda, N. Neurons induce the activation of microglial cells in vitro. Exp. Neurol. 1998, 154, 499-510. [CrossRef]

28. Zhang, W.; Wang, T.; Pei, Z.; Miller, D.S.; Wu, X.; Block, M.L.; Wilson, B.; Zhang, W.; Zhou, Y.; Hong, J.S.; et al. Aggregated $\alpha$-synuclein activates microglia: A process leading to disease progression in Parkinson's disease. FASEB J. 2005, 19, 533-542. [CrossRef]

29. Ezcurra, A.L.D.L.; Chertoff, M.; Ferrari, C.; Graciarena, M.; Pitossi, F. Chronic expression of low levels of tumor necrosis factor- $\alpha$ in the substantia nigra elicits progressive neurodegeneration, delayed motor symptoms and microglia/macrophage activation. Neurobiol. Dis. 2010, 37, 630-640. [CrossRef]

30. Kim, Y.S.; Joh, T.H. Microglia, major player in the brain inflammation: Their roles in the pathogenesis of Parkinson's disease. Exp. Mol. Med. 2006, 38, 333-347. [CrossRef]

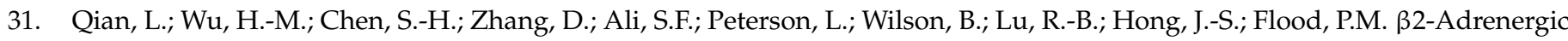
Receptor Activation Prevents Rodent Dopaminergic Neurotoxicity by Inhibiting Microglia via a Novel Signaling Pathway. J. Immunol. 2011, 186, 4443-4454. [CrossRef]

32. dos-Santos-Pereira, M.; Acuña, L.; Hamadat, S.; Rocca, J.; González-Lizárraga, F.; Chehín, R.; Sepulveda-Diaz, J.; Del-Bel, E.; Raisman-Vozari, R.; Michel, P.P. Microglial glutamate release evoked by $\alpha$-synuclein aggregates is prevented by dopamine. Glia 2018, 66, 2353-2365. [CrossRef] 
33. Liddelow, S.A.; Guttenplan, K.A.; Clarke, L.E.; Bennett, F.C.; Bohlen, C.J.; Schirmer, L.; Bennett, M.L.; Münch, A.E.; Chung, W.-S.; Peterson, T.C.; et al. Neurotoxic reactive astrocytes are induced by activated microglia. Nature 2017, 541, 481-487. [CrossRef] [PubMed]

34. Lazzarini, M.; Martin, S.; Mitkovski, M.; Vozari, R.R.; Stühmer, W.; Del Bel, E. Doxycycline restrains glia and confers neuroprotection in a 6-OHDA Parkinson model. Glia 2013, 61, 1084-1100. [CrossRef]

35. Kirkley, K.S.; Popichak, K.A.; Afzali, M.F.; Legare, M.E.; Tjalkens, R.B. Microglia amplify inflammatory activation of astrocytes in manganese neurotoxicity. J. Neuroinflamm. 2017, 14, 99. [CrossRef]

36. Toku, K.; Tanaka, J.; Yano, H.; Desaki, J.; Zhang, B.; Yang, L.; Ishihara, K.; Sakanaka, M.; Maeda, N. Microglial cells prevent nitric oxide-induced neuronal apoptosis in vitro. J. Neurosci. Res. 1998, 53, 415-425. [CrossRef]

37. Tanaka, J.; Toku, K.; Zhang, B.; Ishihara, K.; Sakanaka, M.; Maeda, N. Astrocytes prevent neuronal death induced by reactive oxygen and nitrogen species. Glia 1999, 28, 85-96. [CrossRef]

38. Islam, A.; Choudhury, M.E.; Kigami, Y.; Utsunomiya, R.; Matsumoto, S.; Watanabe, H.; Kumon, Y.; Kunieda, T.; Yano, H.; Tanaka, J. Sustained anti-inflammatory effects of TGF-beta1 on microglia/macrophages. Biochim. Biophys. Acta 2018, 1864, 721-734. [CrossRef] [PubMed]

39. Sugimoto, K.; Nishioka, R.; Ikeda, A.; Mise, A.; Takahashi, H.; Yano, H.; Kumon, Y.; Ohnishi, T.; Tanaka, J. Activated microglia in a rat stroke model express NG2 proteoglycan in peri-infarct tissue through the involvement of TGF-beta1. Glia 2014, 62, 185-198. [CrossRef] [PubMed]

40. Smirkin, A.; Matsumoto, H.; Takahashi, H.; Inoue, A.; Tagawa, M.; Ohue, S.; Watanabe, H.; Yano, H.; Kumon, Y.; Ohnishi, T.; et al. Iba1+/NG2+ Macrophage-Like Cells Expressing a Variety of Neuroprotective Factors Ameliorate Ischemic Damage of the Brain. Br. J. Pharmacol. 2009, 30, 603-615. [CrossRef]

41. Matsumoto, S.; Tanaka, J.; Yano, H.; Takahashi, H.; Sugimoto, K.; Ohue, S.; Inoue, A.; Aono, H.; Kusakawa, A.; Watanabe, H.; et al. CD200+ and CD200 - macrophages accumulated in ischemic lesions of rat brain: The two populations cannot be classified as either M1 or M2 macrophages. J. Neuroimmunol. 2015, 282, 7-20. [CrossRef]

42. Murata, Y.; Sugimoto, K.; Yang, C.; Harada, K.; Gono, R.; Harada, T.; Miyashita, Y.; Higashisaka, K.; Katada, R.; Tanaka, J.; et al. Activated microglia-derived macrophage-like cells exacerbate brain edema after ischemic stroke correlate with astrocytic expression of aquaporin-4 and interleukin-1 alpha release. Neurochem. Int. 2020, 140, 104848. [CrossRef]

43. Chhor, V.; Le Charpentier, T.; Lebon, S.; Oré, M.-V.; Celador, I.L.; Josserand, J.; Degos, V.; Jacotot, E.; Hagberg, H.; Sävman, K.; et al. Characterization of phenotype markers and neuronotoxic potential of polarised primary microglia in vitro. Brain Behav. Immun. 2013, 32, 70-85. [CrossRef] [PubMed]

44. Yu, N.; Zhang, X.; Magistretti, P.J.; Bloom, F.E. IL-1-Alpha and TNF-Alpha Differentially Regulate CD4 and Mac-1 Expression in Mouse Microglia. Neuroimmunomodulation 1998, 5, 42-52. [CrossRef] [PubMed]

45. Takeuchi, H.; Jin, S.; Wang, J.; Zhang, G.; Kawanokuchi, J.; Kuno, R.; Sonobe, Y.; Mizuno, T.; Suzumura, A. Tumor Necrosis Factor- $\alpha$ Induces Neurotoxicity via Glutamate Release from Hemichannels of Activated Microglia in an Autocrine Manner. J. Biol. Chem. 2006, 281, 21362-21368. [CrossRef]

46. Higaki, H.; Choudhury, M.E.; Kawamoto, C.; Miyamoto, K.; Islam, A.; Ishii, Y.; Miyanishi, K.; Takeda, H.; Seo, N.; Sugimoto, K.; et al. The hypnotic bromovalerylurea ameliorates 6-hydroxydopamine-induced dopaminergic neuron loss while suppressing expression of interferon regulatory factors by microglia. Neurochem. Int. 2016, 99, 158-168. [CrossRef] [PubMed]

47. Tei, N.; Tanaka, J.; Sugimoto, K.; Nishihara, T.; Nishioka, R.; Takahashi, H.; Yano, H.; Matsumoto, S.; Ohue, S.; Watanabe, H.; et al. Expression of MCP-1 and fractalkine on endothelial cells and astrocytes may contribute to the invasion and migration of brain macrophages in ischemic rat brain lesions. J. Neurosci. Res. 2013, 91, 681-693. [CrossRef]

48. Liva, S.M.; de Vellis, J. IL-5 induces proliferation and activation of microglia via an unknown receptor. Neurochem. Res. 2001, 26, 629-637. [CrossRef]

49. Franciosi, S.; Choi, H.B.; Kim, S.U.; McLarnon, J.G. IL-8 enhancement of amyloid-beta (Abeta 1-42)-induced expression and production of pro-inflammatory cytokines and COX-2 in cultured human microglia. J. Neuroimmunol. 2005, 159, 66-74. [CrossRef]

50. Pahan, K.; Sheikh, F.G.; Liu, X.; Hilger, S.; McKinney, M.; Petro, T.M. Induction of nitric-oxide synthase and activation of NF-kappaB by interleukin-12 p40 in microglial cells. J. Biol. Chem. 2001, 276, 7899-7905. [CrossRef]

51. Hanisch, U.-K.; Lyons, S.A.; Prinz, M.; Nolte, C.; Weber, J.R.; Kettenmann, H.; Kirchhoff, F. Mouse Brain Microglia Express Interleukin-15 and Its Multimeric Receptor Complex Functionally Coupled to Janus Kinase Activity. J. Biol. Chem. 1997, 272, 28853-28860. [CrossRef]

52. Wheeler, R.D.; Brough, D.; A Le Feuvre, R.; Takeda, K.; Iwakura, Y.; Luheshi, G.N.; Rothwell, N.J. Interleukin-18 induces expression and release of cytokines from murine glial cells: Interactions with interleukin-1 beta. J. Neurochem. 2003, 85, 1412-1420. [CrossRef]

53. Vijitruth, R.; Liu, M.; Choi, D.Y.; Nguyen, X.V.; Hunter, R.L.; Bing, G. Cyclooxygenase-2 mediates microglial activation and secondary dopaminergic cell death in the mouse MPTP model of Parkinson's disease. J. Neuroinflamm. 2006, 3, 6. [CrossRef]

54. Tang, Z.; Arjunan, P.; Lee, C.; Li, Y.; Kumar, A.; Hou, X.; Wang, B.; Wardega, P.; Zhang, F.; Dong, L.; et al. Survival effect of PDGF-CC rescues neurons from apoptosis in both brain and retina by regulating GSK3beta phosphorylation. J. Exp. Med. 2010, 207, 867-880. [CrossRef] [PubMed] 
55. Choudhury, M.; Sugimoto, K.; Kubo, M.; Iwaki, H.; Tsujii, T.; Kyaw, W.; Nishikawa, N.; Nagai, M.; Tanaka, J.; Nomoto, M. Zonisamide up-regulated the mRNAs encoding astrocytic anti-oxidative and neurotrophic factors. Eur. J. Pharmacol. 2012, 689, 72-80. [CrossRef]

56. Liu, X.S.; Li, J.F.; Wang, S.S.; Wang, Y.T.; Zhang, Y.Z.; Yin, H.L.; Geng, S.; Gong, H.C.; Han, B.; Wang, Y.L. Human umbilical cord mesenchymal stem cells infected with adenovirus expressing HGF promote regeneration of damaged neuron cells in a Parkinson's disease model. Biomed. Res. Int. 2014, 2014, 909657. [CrossRef] [PubMed]

57. Wu, S.-Y.; Pan, B.-S.; Tsai, S.-F.; Chiang, Y.-T.; Huang, B.-M.; Mo, F.-E.; Kuo, Y.-M. BDNF reverses aging-related microglial activation. J. Neuroinflamm. 2020, 17, 1-18. [CrossRef]

58. Caldwell, R.W.; Rodriguez, P.C.; Toque, H.A.; Narayanan, S.P. Arginase: A Multifaceted Enzyme Important in Health and Disease. Physiol. Rev. 2018, 98, 641-665. [CrossRef]

59. Chang, Y.-P.; Fang, K.-M.; Lee, T.-I.; Tzeng, S.-F. Regulation of microglial activities by glial cell line derived neurotrophic factor. J. Cell. Biochem. 2006, 97, 501-511. [CrossRef] [PubMed]

60. Chen, X.; Choi, I.Y.; Chang, T.S.; Noh, Y.H.; Shin, C.Y.; Wu, C.F.; Ko, K.H.; Kim, W.K. Pretreatment with interferon-gamma protects microglia from oxidative stress via up-regulation of Mn-SOD. Free Radic. Biol. Med. 2009, 46, 1204-1210. [CrossRef] [PubMed]

61. Wen, T.-C.; Tanaka, J.; Peng, H.; Desaki, J.; Matsuda, S.; Maeda, N.; Fujita, H.; Sato, K.; Sakanaka, M. Interleukin 3 Prevents Delayed Neuronal Death in the Hippocampal CA1 Field. J. Exp. Med. 1998, 188, 635-649. [CrossRef] [PubMed]

62. Hühner, L.; Rilka, J.; Gilsbach, R.; Zhou, X.; Machado, V.; Spittau, B. Interleukin-4 Protects Dopaminergic Neurons In vitro but Is Dispensable for MPTP-Induced Neurodegeneration In vivo. Front. Mol. Neurosci. 2017, 10, 62. [CrossRef]

63. Gao, Y.; Tu, D.; Yang, R.; Chu, C.-H.; Hong, J.-S.; Gao, H.-M. Through Reducing ROS Production, IL-10 Suppresses Caspase-1Dependent IL-1 $\beta$ Maturation, thereby Preventing Chronic Neuroinflammation and Neurodegeneration. Int. J. Mol. Sci. 2020, 21, 465. [CrossRef]

64. de la Fuente-Fernandez, R.; Schulzer, M.; Kuramoto, L.; Cragg, J.; Ramachandiran, N.; Au, W.L.; Mak, E.; McKenzie, J.; McCormick, S.; Sossi, V. Age-specific progression of nigrostriatal dysfunction in Parkinson's disease. Ann. Neurol. 2011, 69, 803-810. [CrossRef]

65. Bezard, E.; Gross, C.E.; Brotchie, J.M. Presymptomatic compensation in Parkinson's disease is not dopamine-mediated. Trends Neurosci. 2003, 26, 215-221. [CrossRef]

66. Arkadir, D.; Bergman, H.; Fahn, S. Redundant dopaminergic activity may enable compensatory axonal sprouting in Parkinson disease. Neurology 2014, 82, 1093-1098. [CrossRef]

67. Bezard, E.; Boraud, T.; Bioulac, B.; Gross, C. Compensatory effects of glutamatergic inputs to the substantia nigra pars compacta in experimental Parkinsonism. Neuroscience 1997, 81, 399-404. [CrossRef]

68. Aono, H.; Choudhury, M.E.; Higaki, H.; Miyanishi, K.; Kigami, Y.; Fujita, K.; Akiyama, J.-I.; Takahashi, H.; Yano, H.; Kubo, M.; et al. Microglia may compensate for dopaminergic neuron loss in experimental Parkinsonism through selective elimination of glutamatergic synapses from the subthalamic nucleus. Glia 2017, 65, 1833-1847. [CrossRef] [PubMed]

69. Takakusaki, K.; Habaguchi, T.; Ohtinata-Sugimoto, J.; Saitoh, K.; Sakamoto, T. Basal ganglia efferents to the brainstem centers controlling postural muscle tone and locomotion: A new concept for understanding motor disorders in basal ganglia dysfunction. Neuroscience 2003, 119, 293-308. [CrossRef]

70. Calabresi, P.; Picconi, B.; Tozzi, A.; Ghiglieri, V.; Di Filippo, M. Direct and indirect pathways of basal ganglia: A critical reappraisal. Nat. Neurosci. 2014, 17, 1022-1030. [CrossRef] [PubMed]

71. Kravitz, A.V.; Freeze, B.S.; Parker, P.R.L.; Kay, K.; Thwin, M.T.; Deisseroth, K.; Kreitzer, A.C. Regulation of parkinsonian motor behaviours by optogenetic control of basal ganglia circuitry. Nat. Cell Biol. 2010, 466, 622-626. [CrossRef]

72. Takeda, H.; Yamaguchi, T.; Yano, H.; Tanaka, J. Microglial metabolic disturbances and neuroinflammation in cerebral infarction. J. Pharmacol. Sci. 2021, 145, 130-139. [CrossRef]

73. Konishi, H.; Kiyama, H. Microglial TREM2/DAP12 signaling: A double-edged sword in neural diseases. Front. Cell. Neurosci. 2018, 12, 206. [CrossRef]

74. Patel, A.R.; Ritzel, R.; McCullough, L.D.; Liu, F. Microglia and ischemic stroke: A double-edged sword. Int. J. Physiol. Pathophysiol. Pharmacol. 2013, 5, 73-90.

75. Santiago, A.R.; Bernardino, L.; Agudo-Barriuso, M.; Gonçalves, J. Microglia in Health and Disease: A Double-Edged Sword. Mediat. Inflamm. 2017, 2017, 7034143. [CrossRef] [PubMed]

76. Miyanishi, K.; Sato, A.; Kihara, N.; Utsunomiya, R.; Tanaka, J. Synaptic elimination by microglia and disturbed higher brain functions. Neurochem. Int. 2021, 142, 104901. [CrossRef] [PubMed]

77. McColl, B.W.; Rothwell, N.J.; Allan, S.M. Systemic Inflammatory Stimulus Potentiates the Acute Phase and CXC Chemokine Responses to Experimental Stroke and Exacerbates Brain Damage via Interleukin-1- and Neutrophil-Dependent Mechanisms. J. Neurosci. 2007, 27, 4403-4412. [CrossRef]

78. Gao, H.-M.; Kotzbauer, P.T.; Uryu, K.; Leight, S.; Trojanowski, J.Q.; Lee, V.M.-Y. Neuroinflammation and Oxidation/Nitration of -Synuclein Linked to Dopaminergic Neurodegeneration. J. Neurosci. 2008, 28, 7687-7698. [CrossRef] [PubMed]

79. Long-Smith, C.M.; Sullivan, A.M.; Nolan, Y.M. The influence of microglia on the pathogenesis of Parkinson's disease. Prog. Neurobiol. 2009, 89, 277-287. [CrossRef] [PubMed] 
80. Marinova-Mutafchieva, L.; Sadeghian, M.; Broom, L.; Davis, J.B.; Medhurst, A.D.; Dexter, D.T. Relationship between microglial activation and dopaminergic neuronal loss in the substantia nigra: A time course study in a 6-hydroxydopamine model of Parkinson's disease. J. Neurochem. 2009, 110, 966-975. [CrossRef] [PubMed]

81. Tanaka, J.; Fujita, H.; Matsuda, S.; Toku, K.; Sakanaka, M.; Maeda, N. Glucocorticoid- and mineralocorticoid receptors in microglial cells: The two receptors mediate differential effects of corticosteroids. Glia 1997, 20, 23-37. [CrossRef]

82. Ishii, Y.; Yamaizumi, A.; Kawakami, A.; Islam, A.; Choudhury, M.E.; Takahashi, H.; Yano, H.; Tanaka, J. Anti-inflammatory effects of noradrenaline on LPS-treated microglial cells: Suppression of NFkappaB nuclear translocation and subsequent STAT1 phosphorylation. Neurochem. Int. 2015, 90, 56-66. [CrossRef]

83. Lin, L.; Doherty, D.; Lile, J.; Bektesh, S.; Collins, F. GDNF: A glial cell line-derived neurotrophic factor for midbrain dopaminergic neurons. Science 1993, 260, 1130-1132. [CrossRef]

84. Ridet, J.; Privat, A.; Malhotra, S.; Gage, F. Reactive astrocytes: Cellular and molecular cues to biological function. Trends Neurosci. 1997, 20, 570-577. [CrossRef]

85. Tanaka, J.; Toku, K.; Sakanaka, M.; Maeda, N. Morphological differentiation of microglial cells in culture: Involvement of insoluble factors derived from astrocytes. Neurosci. Res. 1999, 34, 207-215. [CrossRef]

86. Tanaka, J.; Maeda, N. Microglial Ramification Requires Nondiffusible Factors Derived from Astrocytes. Exp. Neurol. 1996, 137, 367-375. [CrossRef] [PubMed]

87. Kouli, A.; Camacho, M.; Allinson, K.; Williams-Gray, C.H. Neuroinflammation and protein pathology in Parkinson's disease dementia. Acta Neuropathol. Commun. 2020, 8, 1-19. [CrossRef]

88. Dzamko, N.; Gysbers, A.; Perera, G.; Bahar, A.; Shankar, A.; Gao, J.; Fu, Y.; Halliday, G.M. Toll-like receptor 2 is increased in neurons in Parkinson's disease brain and may contribute to alpha-synuclein pathology. Acta Neuropathol. 2017, 133, 303-319. [CrossRef]

89. Fiebich, B.L.; Batista, C.R.A.; Saliba, S.W.; Yousif, N.M.; De Oliveira, A.C.P. Role of Microglia TLRs in Neurodegeneration. Front. Cell. Neurosci. 2018, 12, 329. [CrossRef]

90. Noelker, C.; Morel, L.; Lescot, T.; Osterloh, A.; Alvarez-Fischer, D.; Breloer, M.; Henze, C.; Depboylu, C.; Skrzydelski, D.; Michel, P.P.; et al. Toll like receptor 4 mediates cell death in a mouse MPTP model of Parkinson disease. Sci. Rep. 2013, 3, 1393. [CrossRef]

91. Shi, H.; Hua, X.; Kong, D.; Stein, D.; Hua, F. Role of Toll-like receptor mediated signaling in traumatic brain injury. Neuropharmacology 2019, 145, 259-267. [CrossRef]

92. Gou, X.; Ying, J.; Yue, Y.; Qiu, X.; Hu, P.; Qu, Y.; Li, J.; Mu, D. The Roles of High Mobility Group Box 1 in Cerebral Ischemic Injury. Front. Cell. Neurosci. 2020, 14. [CrossRef] [PubMed]

93. Stefanova, N.; Fellner, L.; Reindl, M.; Masliah, E.; Poewe, W.; Wenning, G.K. Toll-Like Receptor 4 Promotes $\alpha$-Synuclein Clearance and Survival of Nigral Dopaminergic Neurons. Am. J. Pathol. 2011, 179, 954-963. [CrossRef]

94. Sarkar, S.; Dammer, E.B.; Malovic, E.; Olsen, A.L.; Raza, S.A.; Gao, T.; Xiao, H.; Oliver, D.L.; Duong, D.; Joers, V.; et al. Molecular Signatures of Neuroinflammation Induced by $\alpha$ Synuclein Aggregates in Microglial Cells. Front. Immunol. 2020, 11, 33. [CrossRef] [PubMed]

95. Zhang, J.; Dongwei, Z.; Zhang, Z.; Xinhui, Q.; Kunwang, B.; Guohui, L.; Jian, D. miR-let-7a suppresses alpha-Synuclein-induced microglia inflammation through targeting STAT3 in Parkinson's disease. Biochem. Biophys. Res. Commun. 2019, 519, 740-746. [CrossRef] [PubMed]

96. Choudhury, M.E.; Miyanishi, K.; Takeda, H.; Islam, A.; Matsuoka, N.; Kubo, M.; Matsumoto, S.; Kunieda, T.; Nomoto, M.; Yano, H.; et al. Phagocytic elimination of synapses by microglia during sleep. Glia 2020, 68, 44-59. [CrossRef] [PubMed]

97. Sugama, S.; Kakinuma, Y. Noradrenaline as a key neurotransmitter in modulating microglial activation in stress response. Neurochem. Int. 2021, 143, 104943. [CrossRef]

98. Valko, M.; Leibfritz, D.; Moncol, J.; Cronin, M.T.D.; Mazur, M.; Telser, J. Free radicals and antioxidants in normal physiological functions and human disease. Int. J. Biochem. Cell Biol. 2007, 39, 44-84. [CrossRef] [PubMed]

99. Block, M.L.; Zecca, L.; Hong, J.-S. Microglia-mediated neurotoxicity: Uncovering the molecular mechanisms. Nat. Rev. Neurosci. 2007, 8, 57-69. [CrossRef] [PubMed]

100. Cherry, J.D.; A Olschowka, J.; O'Banion, M.K. Neuroinflammation and M2 microglia: The good, the bad, and the inflamed. J. Neuroinflamm. 2014, 11, 98. [CrossRef] [PubMed]

101. Ransohoff, R.M. A polarizing question: Do M1 and M2 microglia exist? Nat. Neurosci. 2016, 19, 987-991. [CrossRef]

102. Brown, G.C.; Neher, J.J. Microglial phagocytosis of live neurons. Nat. Rev. Neurosci. 2014, 15, 209-216. [CrossRef] [PubMed]

103. Emmrich, J.V.; Hornik, T.C.; Neher, J.J.; Brown, G.C. Rotenone induces neuronal death by microglial phagocytosis of neurons. FEBS J. 2013, 280, 5030-5038. [CrossRef]

104. Schäbitz, W.-R.; Krüger, C.; Pitzer, C.; Weber, D.; Laage, R.; Gassler, N.; Aronowski, J.; Mier, W.; Kirsch, F.; Dittgen, T.; et al. A Neuroprotective Function for the Hematopoietic Protein Granulocyte-Macrophage Colony Stimulating Factor (GM-CSF). Br. J. Pharmacol. 2007, 28, 29-43. [CrossRef] [PubMed]

105. Nishihara, T.; Ochi, M.; Sugimoto, K.; Takahashi, H.; Yano, H.; Kumon, Y.; Ohnishi, T.; Tanaka, J. Subcutaneous injection containing IL-3 and GM-CSF ameliorates stab wound-induced brain injury in rats. Exp. Neurol. 2011, 229, 507-516. [CrossRef] [PubMed] 
106. Fujita, H.; Tanaka, J.; Toku, K.; Tateishi, N.; Suzuki, Y.; Matsuda, S.; Sakanaka, M.; Maeda, N. Effects of GM-CSF and ordinary supplements on the ramification of microglia in culture: A morphometrical study. Glia 1996, 18, 269-281. [CrossRef]

107. Tanaka, J.; Toku, K.; Matsuda, S.; Sudo, S.; Fujita, H.; Sakanaka, M.; Maeda, N. Induction of resting microglia in culture medium devoid of glycine and serine. Glia 1998, 24, 198-215. [CrossRef]

108. Liu, Y.; Aguzzi, A. NG2 glia are required for maintaining microglia homeostatic state. Glia 2020, 68, 345-355. [CrossRef]

109. Matsumoto, H.; Kumon, Y.; Watanabe, H.; Ohnishi, T.; Shudou, M.; Chuai, M.; Imai, Y.; Takahashi, H.; Tanaka, J. Accumulation of Macrophage-Like Cells Expressing NG2 Proteoglycan and Iba1 in Ischemic Core of Rat Brain after Transient Middle Cerebral Artery Occlusion. Br. J. Pharmacol. 2007, 28, 149-163. [CrossRef]

110. Dimou, L.; Gallo, V. NG2-glia and their functions in the central nervous system. Glia 2015, 63, 1429-1451. [CrossRef]

111. Hill, R.A.; Nishiyama, A. NG2 cells (polydendrocytes): Listeners to the neural network with diverse properties. Glia 2014, 62, 1195-1210. [CrossRef]

112. Richardson, W.D.; Young, K.M.; Tripathi, R.B.; McKenzie, I. NG2-glia as Multipotent Neural Stem Cells: Fact or Fantasy? Neuron 2011, 70, 661-673. [CrossRef] [PubMed]

113. Ohya, W.; Funakoshi, H.; Kurosawa, T.; Nakamura, T. Hepatocyte growth factor (HGF) promotes oligodendrocyte progenitor cell proliferation and inhibits its differentiation during postnatal development in the rat. Brain Res. 2007, 1147, 51-65. [CrossRef] [PubMed]

114. Wu, D.C.; Jackson-Lewis, V.; Vila, M.; Tieu, K.; Teismann, P.; Vadseth, C.; Choi, D.-K.; Ischiropoulos, H.; Przedborski, S. Blockade of Microglial Activation Is Neuroprotective in the 1-Methyl-4-Phenyl-1,2,3,6-Tetrahydropyridine Mouse Model of Parkinson Disease. J. Neurosci. 2002, 22, 1763-1771. [CrossRef] [PubMed]

115. Manso, Y.; Holland, P.R.; Kitamura, A.; Szymkowiak, S.; Duncombe, J.; Hennessy, E.; Searcy, J.L.; Marangoni, M.; Randall, A.D.; Brown, J.T.; et al. Minocycline reduces microgliosis and improves subcortical white matter function in a model of cerebral vascular disease. Glia 2018, 66, 34-46. [CrossRef]

116. Möller, T.; Bard, F.; Bhattacharya, A.; Biber, K.; Campbell, B.; Dale, E.; Eder, C.; Gan, L.; Garden, G.A.; Hughes, Z.A.; et al. Critical data-based re-evaluation of minocycline as a putative specific microglia inhibitor. Glia 2016, 64, 1788-1794. [CrossRef]

117. The NINDS NET-PD Investigators. A randomized, double-blind, futility clinical trial of creatine and minocycline in early Parkinson disease. Neurology 2006, 66, 664-671. [CrossRef]

118. Ninds Net-Pd Investigators. A pilot clinical trial of creatine and minocycline in early parkinson disease: 18-month results. Clin. Neuropharmacol. 2008, 31, 141-150. [CrossRef]

119. Kawasaki, S.; Abe, N.; Ohtake, F.; Islam, A.; Choudhury, M.E.; Utsunomiya, R.; Kikuchi, S.; Nishihara, T.; Kuwabara, J.; Yano, H.; et al. Effects of hypnotic bromovalerylurea on microglial BV2 cells. J. Pharmacol. Sci. 2017, 134, 116-123. [CrossRef]

120. Kikuchi, S.; Nishihara, T.; Kawasaki, S.; Abe, N.; Kuwabara, J.; Choudhury, M.E.; Takahashi, H.; Yano, H.; Nagaro, T.; Watanabe, Y.; et al. The ameliorative effects of a hypnotic bromvalerylurea in sepsis. Biochem. Biophys. Res. Commun. 2015, 459, 319-326. [CrossRef]

121. Bernheimer, H.; Birkmayer, W.; Hornykiewicz, O.; Jellinger, K.; Seitelberger, F. Brain dopamine and the syndromes of Parkinson and Huntington Clinical, morphological and neurochemical correlations. J. Neurol. Sci. 1973, 20, 415-455. [CrossRef]

122. Perez, X.A.; Parameswaran, N.; Huang, L.Z.; O'Leary, K.T.; Quik, M. Pre-synaptic dopaminergic compensation after moderate nigrostriatal damage in non-human primates. J. Neurochem. 2008, 105, 1861-1872. [CrossRef] [PubMed]

123. Olsson, M.; Nikkhah, G.; Bentlage, C.; Bjorklund, A. Forelimb akinesia in the rat Parkinson model: Differential effects of dopamine agonists and nigral transplants as assessed by a new stepping test. J. Neurosci. 1995, 15, 3863-3875. [CrossRef]

124. Domercq, M.; Vázquez-Villoldo, N.; Matute, C. Neurotransmitter signaling in the pathophysiology of microglia. Front. Cell. Neurosci. 2013, 7, 49. [CrossRef]

125. Pocock, J.M.; Kettenmann, H. Neurotransmitter receptors on microglia. Trends Neurosci. 2007, 30, 527-535. [CrossRef] [PubMed]

126. Murugan, M.; Ling, E.-A.; Kaur, C. Glutamate receptors in microglia. CNS Neurol. Disord. Drug Targets 2013, 12, 773-784. [CrossRef] [PubMed]

127. Fontainhas, A.M.; Wang, M.; Liang, K.J.; Chen, S.; Mettu, P.; Damani, M.; Fariss, R.N.; Li, W.; Wong, W.T. Microglial Morphology and Dynamic Behavior Is Regulated by Ionotropic Glutamatergic and GABAergic Neurotransmission. PLoS ONE 2011, 6, e15973. [CrossRef] [PubMed]

128. Li, Y.; Du, X.-F.; Liu, C.-S.; Wen, Z.-L.; Du, J.-L. Reciprocal Regulation between Resting Microglial Dynamics and Neuronal Activity In Vivo. Dev. Cell 2012, 23, 1189-1202. [CrossRef] [PubMed]

129. Rodriguez-Oroz, M.C.; Obeso, J.A.; Lang, A.E.; Houeto, J.L.; Pollak, P.; Rehncrona, S.; Kulisevsky, J.; Albanese, A.; Volkmann, J.; Hariz, M.I.; et al. Bilateral deep brain stimulation in Parkinson's disease: A multicentre study with 4 years follow-up. Brain 2005, 128, 2240-2249. [CrossRef]

130. Witt, K.; Daniels, C.; Reiff, J.; Krack, P.; Volkmann, J.; Pinsker, M.O.; Krause, M.; Tronnier, V.; Kloss, M.; Schnitzler, A.; et al. Neuropsychological and psychiatric changes after deep brain stimulation for Parkinson's disease: A randomised, multicentre study. Lancet Neurol. 2008, 7, 605-614. [CrossRef]

131. Drummond, N.M.; Chen, R. Deep brain stimulation and recordings: Insights into the contributions of subthalamic nucleus in cognition. NeuroImage 2020, 222, 117300. [CrossRef]

132. Hemmerle, A.M.; Herman, J.P.; Seroogy, K.B. Stress, depression and Parkinson's disease. Exp. Neurol. 2012, 233, 79-86. [CrossRef] 
133. Austin, K.W.; Ameringer, S.W.; Cloud, L.J. An Integrated Review of Psychological Stress in Parkinson's Disease: Biological Mechanisms and Symptom and Health Outcomes. Park. Dis. 2016, 2016, 1-15. [CrossRef] [PubMed]

134. Trivino, J.J.; von Bernhardi, R. The effect of aged microglia on synaptic impairment and its relevance in neurodegenerative diseases. Neurochem. Int. 2021, 144, 104982. [CrossRef]

135. Davies, D.S.; Ma, J.; Jegathees, T.; Goldsbury, C. Microglia show altered morphology and reduced arborization in human brain during aging and Alzheimer's disease. Brain Pathol. 2017, 27, 795-808. [CrossRef] [PubMed]

136. O'Neil, S.M.; Witcher, K.G.; McKim, D.B.; Godbout, J.P. Forced turnover of aged microglia induces an intermediate phenotype but does not rebalance CNS environmental cues driving priming to immune challenge. Acta Neuropathol. Commun. 2018, 6, 1-20. [CrossRef] [PubMed]

137. Streit, W.J.; Sammons, N.W.; Kuhns, A.J.; Sparks, D.L. Dystrophic microglia in the aging human brain. Glia 2004, 45, $208-212$. [CrossRef] [PubMed]

138. Galatro, T.F.; Holtman, I.R.; Lerario, A.M.; Vainchtein, I.D.; Brouwer, N.; Sola, P.R.; Veras, M.M.; Pereira, T.F.; Leite, R.E.P.; Möller, T.; et al. Transcriptomic analysis of purified human cortical microglia reveals age-associated changes. Nat. Neurosci. 2017, 20, 1162-1171. [CrossRef]

139. Henry, C.J.; Huang, Y.; Wynne, A.M.; Godbout, J.P. Peripheral lipopolysaccharide (LPS) challenge promotes microglial hyperactivity in aged mice that is associated with exaggerated induction of both pro-inflammatory IL-1beta and anti-inflammatory IL-10 cytokines. Brain Behav. Immun. 2009, 23, 309-317. [CrossRef]

140. VanGuilder, H.D.; Bixler, G.V.; Brucklacher, R.M.; A Farley, J.; Yan, H.; Warrington, J.P.; E Sonntag, W.; Freeman, W.M. Concurrent hippocampal induction of MHC II pathway components and glial activation with advanced aging is not correlated with cognitive impairment. J. Neuroinflamm. 2011, 8, 138. [CrossRef]

141. Griffin, R.; Nally, R.; Nolan, Y.; McCartney, Y.; Linden, J.; Lynch, M.A. The age-related attenuation in long-term potentiation is associated with microglial activation. J. Neurochem. 2006, 99, 1263-1272. [CrossRef]

142. Letiembre, M.; Hao, W.; Liu, Y.; Walter, S.; Mihaljevic, I.; Rivest, S.; Hartmann, T.; Fassbender, K. Innate immune receptor expression in normal brain aging. Neuroscience 2007, 146, 248-254. [CrossRef] [PubMed]

143. Mrdjen, D.; Pavlovic, A.; Hartmann, F.J.; Schreiner, B.; Utz, S.G.; Leung, B.P.; Lelios, I.; Heppner, F.L.; Kipnis, J.; Merkler, D.; et al. High-Dimensional Single-Cell Mapping of Central Nervous System Immune Cells Reveals Distinct Myeloid Subsets in Health, Aging, and Disease. Immunity 2018, 48, 380-395.e6. [CrossRef] [PubMed]

144. Calabrese, V.; Santoro, A.; Monti, D.; Crupi, R.; Di Paola, R.; Latteri, S.; Cuzzocrea, S.; Zappia, M.; Giordano, J.; Calabrese, E.J.; et al. Aging and Parkinson's Disease: Inflammaging, neuroinflammation and biological remodeling as key factors in pathogenesis. Free Radic. Biol. Med. 2018, 115, 80-91. [CrossRef] [PubMed]

145. Cornejo, F.; von Bernhardi, R. Age-Dependent Changes in the Activation and Regulation of Microglia. Adv. Exp. Med. Biol. 2016, 949, 205-226.

146. Zöller, T.; Attaai, A.; Potru, P.S.; Ruß, T.; Spittau, B. Aged Mouse Cortical Microglia Display an Activation Profile Suggesting Immunotolerogenic Functions. Int. J. Mol. Sci. 2018, 19, 706. [CrossRef] [PubMed]

147. Hart, A.D.; Wyttenbach, A.; Perry, V.H.; Teeling, J.L. Age related changes in microglial phenotype vary between CNS regions: Grey versus white matter differences. Brain Behav. Immun. 2012, 26, 754-765. [CrossRef]

148. Bliederhaeuser, C.; Grozdanov, V.; Speidel, A.; Zondler, L.; Ruf, W.P.; Bayer, H.; Kiechle, M.; Feiler, M.S.; Freischmidt, A.; Brenner, D.; et al. Age-dependent defects of alpha-synuclein oligomer uptake in microglia and monocytes. Acta Neuropathol. 2015, 131, 379-391. [CrossRef]

149. Heneka, M.T.; Nadrigny, F.; Regen, T.; Martinez-Hernandez, A.; Dumitrescu-Ozimek, L.; Terwel, D.; Jardanhazi-Kurutz, D.; Walter, J.; Kirchhoff, F.; Hanisch, U.K.; et al. Locus ceruleus controls Alzheimer's disease pathology by modulating microglial functions through norepinephrine. Proc. Natl. Acad. Sci. USA 2010, 107, 6058-6063. [CrossRef]

150. Mori, K.; Ozaki, E.; Zhang, B.; Yang, L.; Yokoyama, A.; Takeda, I.; Maeda, N.; Sakanaka, M.; Tanaka, J. Effects of norepinephrine on rat cultured microglial cells that express alpha1, alpha2, beta1 and beta2 adrenergic receptors. Neuropharmacology 2002, 43, 1026-1034. [CrossRef]

151. Zhang, B.; Yang, L.; Konishi, Y.; Maeda, N.; Sakanaka, M.; Tanaka, J. Suppressive effects of phosphodiesterase type IV inhibitors on rat cultured microglial cells: Comparison with other types of cAMP-elevating agents. Neuropharmacology 2002, 42, 262-269. [CrossRef]

152. Heneka, M.T.; Carson, M.J.; Khoury, J.E.; Landreth, G.E.; Brosseron, F.; Feinstein, D.L.; Jacobs, A.H.; Wyss-Coray, T.; Vitorica, J.; Ransohoff, R.M.; et al. Neuroinflammation in Alzheimer's disease. Lancet Neurol. 2015, 14, 388-405. [CrossRef]

153. Perry, V.H.; Holmes, C. Microglial priming in neurodegenerative disease. Nat. Rev. Neurol. 2014, 10, 217-224. [CrossRef]

154. Wake, H.; Moorhouse, A.J.; Miyamoto, A.; Nabekura, J. Microglia: Actively surveying and shaping neuronal circuit structure and function. Trends Neurosci. 2013, 36, 209-217. [CrossRef] [PubMed]

155. Tremblay, M.-Ė.; Lowery, R.L.; Majewska, A.K. Microglial Interactions with Synapses Are Modulated by Visual Experience. PLoS Biol. 2010, 8, e1000527. [CrossRef] [PubMed]

156. Verkhratsky, A.; Sun, D.; Tanaka, J. Snapshot of microglial physiological functions. Neurochem. Int. 2021, 144, 104960. [CrossRef]

157. Wang, C.; Yue, H.; Hu, Z.; Shen, Y.; Ma, J.; Li, J.; Wang, X.-D.; Wang, L.; Sun, B.; Shi, P.; et al. Microglia mediate forgetting via complement-dependent synaptic elimination. Science 2020, 367, 688-694. [CrossRef] 
158. Kikutani, K.; Giga, H.; Hosokawa, K.; Shime, N.; Aizawa, H. Microglial translocator protein and stressor-related disorder. Neurochem. Int. 2020, 140, 104855. [CrossRef] [PubMed]

159. Enomoto, S.; Kato, T.A. Involvement of microglia in disturbed fear memory regulation: Possible microglial contribution to the pathophysiology of posttraumatic stress disorder. Neurochem. Int. 2021, 142, 104921. [CrossRef]

160. Matsumoto, H.; Kumon, Y.; Watanabe, H.; Ohnishi, T.; Shudou, M.; Ii, C.; Takahashi, H.; Imai, Y.; Tanaka, J. Antibodies to CD11b, CD68, and lectin label neutrophils rather than microglia in traumatic and ischemic brain lesions. J. Neurosci. Res. 2007, 85, 994-1009. [CrossRef] 